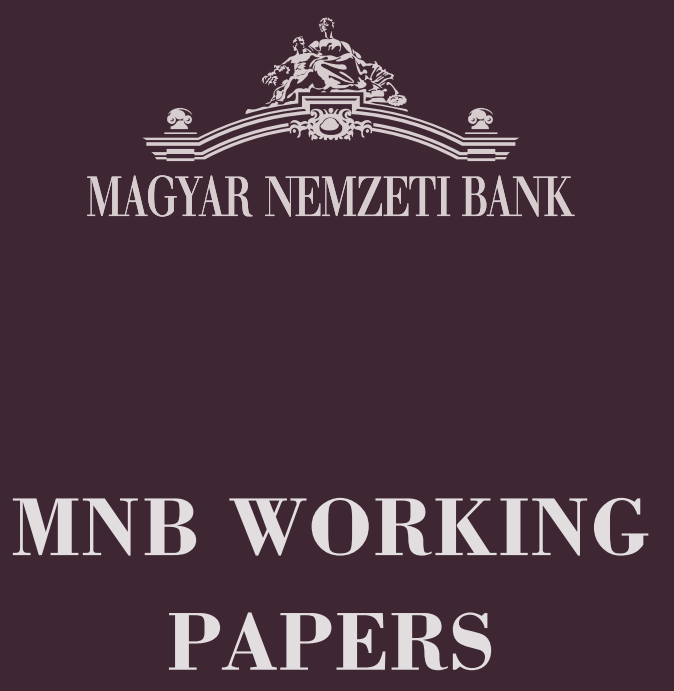

JÓZSEF MOLNÁR-MÁRTON NAGY-CSILLA HORVÁTH

A Structural Empirical Analysis of Retail Banking Competition: the Gase of Hungary 



\section{A Structural Empirical Analysis of Retail Banking Competition: the Case of Hungary}

November 2006 
The MNB Working Paper series includes studies that are aimed to be of interest to the academic community, as well as researchers in central banks and elsewhere. Starting from 9/2005, articles undergo a refereeing process, and their publication is supervised by an editorial board.

The purpose of publishing the Working Paper series is to stimulate comments and suggestions to the work prepared within the Magyar Nemzeti Bank. Citations should refer to a Magyar Nemzeti Bank Working Paper. The views expressed are those of the authors and do not necessarily reflect the official view of the Bank.

MNB Working Papers 2007/1

\title{
A Structural Empirical Analysis of Retail Banking Competition: the Case of Hungary*
}

(A banki verseny elemzése a háztartási szegmensben)

\author{
Written by: József Molnár**-Márton Nagy***_Csilla Horváth****
}

First version: March 2006

This version: November 2006

\author{
Magyar Nemzeti Bank
}

Szabadság tér 8-9, H-1850 Budapest

http://www.mnb.hu

* The views expressed in this paper are those of the authors and do not necessarily correspond to the views of the National Bank of Hungary (Magyar Nemzeti Bank) or of the Bank of Finland. We are grateful to Gábor Kézdi, Szabolcs Lörincz, Alistair Milne for valuable comments and Gábor Kátay, Zoltán Wolf for technical assistance. We also thank seminar participants at the Magyar Nemzeti Bank, the Bank of Finland (Suomen Pankki), University of Mannheim, Helsinki School of Economics and the XV International "Tor Vergata" Conference on Banking and Finance. We are responsible for all the remainig errors.

** Corresponding author: Affiliation: Research Department, Bank of Finland, P.O.Box 160, FIN-00101 Helsinki, Finland.Tel.: +358-10-831-2643, e-mail: jomol72@yahoo.com.

*** Affiliation: Magyar Nemzeti Bank, H-1850 Budapest, Szabadság tér 8-9, Hungary, Telephone: 00-36-1-428-2600 Fax: 00-36-1-428-2590, e-mail: nagymar@mnb.hu.

**** Affiliation: Radboud University Nijmegen - Nijmegen School of Management, Thomas van Aquinostraat 3, P.O. Box 9108, NL - 6500 HK Nijmegen, Netherlands, Telephone: +31-24-361-1476, e-mail:c.horvath@fm.ru.nl. 


\section{Contents}

$\begin{array}{ll}\text { Abstract } & 4\end{array}$

1. Introduction $\quad 5$

2. The Hungarian banking industry $\quad 7$

3. Model 9

3.1 Demand for deposit services and loans $\quad 9$

$\begin{array}{lr}3.2 \text { Supply of deposit services and loans } & 10\end{array}$

4. Demand estimation $\quad 13$

$\begin{array}{lr}\text { 5. Data and variables } & 15\end{array}$

6. Results of demand estimations $\quad 17$

$\begin{array}{ll}6.1 \text { Consumer loans } & 17\end{array}$

6.2 Household deposits $\quad 18$

7. Measuring the degree of competition 19

$\begin{array}{ll}7.1 \text { Cost function } & 19\end{array}$

7.2 Results: "observed" and implied price-cost margins 20

8. Robustness check 22

$\begin{array}{lr}\text { 9. Conclusion } & 24\end{array}$

$\begin{array}{ll}\text { References } & 25\end{array}$

$\begin{array}{ll}\text { Appendix } & 26\end{array}$ 


\begin{abstract}
In this paper we analyze the degree of competition in the Hungarian household credit and deposit markets. We estimate discrete-choice, multinomial logit deposit service and loan demand functions for each bank and calculate the corresponding price elasticities. Two models of the banking industry are considered: a static, differentiated product Nash-Bertrand oligopoly (as non-collusive benchmark) and a cartel. With estimated marginal costs and observed interest rates we calculate the price-cost margins and compare these to the theoretically implied ones. We find that in our sample period the competition in the Hungarian banking sector is low, i.e. price-cost margins are high.
\end{abstract}

JEL Classification: G21, L11, L13.

Keywords: Demand, discrete choice, product differentiation, banking, market power.

\title{
Összefoglalás
}

A tanulmány a korábbi hazai és nemzetközi irodalomhoz képest egy fejlettebb eszközrendszer használ, az un. „diszkrét választás" modelljét. Ez a modell lehetőséget ad arra, hogy a fogyasztói választás során modellezzük a termékdifferenciálás melletti banki árversenyt. Elméleti keretrendszerben megbecslésre, illetve kiszámításra kerül, hogy a hipotetikusan a Bertrand árverseny és tökéletes összejátszás mellett mekkora lenne a bankok profitmarzsa („mark-up”), majd ez összehasonlításra kerül a megfigyelt profitmarzsokkal. A verseny foka abban az esetben tekintető alacsonynak, ha a megfigyelt profitmarzs a Bertrand árverseny és a tökéletes összejátszás marzsai között található. Ha a megfigyelt profitmarzs az elméleti Bertrand pont alá esik, akkor a modell azt sejteti, hogy a verseny foka magas. A tanulmány hat „retail”, illetve lakossági részpiacot vizsgál, hármat a forinthitel (folyószámla, személyi és áruvásárlási hitelpiacokat) és hármat a forintbetéti piacon (látra szóló, rövid futamidejú és hosszú futamidejú betéti piacokat). A vizsgálthoz a 2003 január-2005 december periódusban havi adatok kerülnek felhasználásra. A megfigyelt és az elméleti modell által implikált profitmarzsok miden egyes bankra, minden egyes hónapban kiszámításra kerülnek. A tanulmány ez alapján azt a következtetést vonja le, hogy a verseny foka a folyószámla, áruvásárlási és személyi hitelek, valamint a látra-szóló és a rövid lejáratú hitelek esetén alacsonynak tekinthető. Egyedül a hosszú távú betétek esetén azonosítható versenyzói piac. 


\section{Introduction}

The competitiveness of the banking sector is an important condition for effective economic policy. As the European Commission argued in a recently published report ${ }^{1}$ on retail banking: "Well functioning, integrated and competitive financial markets are essential for an efficient and dynamic development of the European economy. A number of indicators such as market fragmentation and entry barriers as well as a limited choice of retail banking customers, however, suggest that not all financial markets are truly integrated. Furthermore these patterns may suggest that competition may be restricted or distorted within the common market, in particular with respect to the provision of retail banking products and services to consumers and small and medium sized enterprises." The goal of this paper is to complement this EU report's fact finding with a structural economic model of competition in the retail banking sector.

We build a structural model of competition and test our model on data from the Hungarian consumer credit and deposit markets. ${ }^{2}$ We describe two, commonly used models of retail banking competition, a collusive cartel and a differentiated product Nash-Bertrand competition that we consider as a benchmark for non-collusive pricing. For each supply model the pricing decisions depend on the bank-level demand. We estimate demands for consumer-loans and deposits using discrete choice, multinomial logit and nested logit models and bank-level data. This approach is based on uncovering consumer preferences over individual product characteristics from the distribution of the first choices of consumers (market shares.) The estimated demand parameters are then used to calculate the price-cost margins (PCMs) implied by the two supply models. We estimate a translog cost function for individual banks to uncover bank and product specific marginal costs. The estimated cost parameters and the observed interest rates are used to calculate the "observed" PCMs. Finally, we test which theoretical supply model fits the data better.

In the past decades, empirical economists developed several different techniques to examine the degree of competition in oligopolistic industries. The structure-conduct-performance (SCP) paradigm conjectures that in highly concentrated markets, it is easier for dominant firms to collude and raise profits to levels above the competitive one. Papers using this approach usually regress profitability on concentration, which is mostly taken to be exogenous, and frequently find a positive correlation between market concentration and profitability. ${ }^{3}$ The problem with these studies is that the causality, even if the correlation exists, is not clear. The more modern techniques circumvent the problems of SCP approach and aim to infer the conduct of the firms directly without taking market structures into account. The two most popular methodologies are the Panzar-Rosse (1987) test that infers conduct from the individual firm's input-output cost relationships and Bresnahan's (1982) conjectural variation (CV) model that focuses on market structure parameters. There are numerous empirical papers that applied these methods to estimate the level of banking competition for different countries. ${ }^{4}$

Várhegyi (2004) applies the CV method to study the aggregate lending market in Hungary and finds that it is fairly competitive. Móré and Nagy (2004) using the same method, find that the aggregate estimation could be misleading and on the consumers credit and deposit markets banks have significant market power. The CV approach analyzes market conduct by estimating a static, homogenous good Cournot model and assumes that firms maximize profits over output levels based on their expectations on other firms' reactions. As Corts (1999) shows, the CV methodology has several problems related to the irrationality of conjectured reactions in a static setting, the interpretation of the theoretical conduct parameter and the estimation methodology. The criticism in Corts (1999) puts the results of CV studies into perspective. ${ }^{5}$

\footnotetext{
Published on 17 July 2006. The citation is from page 12 .

${ }^{2}$ In Hungary, the degree of retail bank competition also has been a focus of debate. The Hungarian Competition Commission started an examination of the mortgage market because of the "banks' high interest rate, increasing profits and interest margins well above the EU average indicate that the pricecompetition is not sufficient". The inquiry was finished in January 2006 and no banks were fined but the report nonetheless contains suggestions about how banks should inform consumers, refrain from bundling, simplify their fee structures, etc.

${ }^{3}$ For example: Berger and Hannan (1989), Hannan (1997), Hannan and Berger (1991), Berger (1995) reported lower deposit rates, higher loan rates and higher price stickiness in more concentrated markets.

${ }^{4}$ Among many others see for example: De Bandt and Davis (2000), Bikkert and Haaf (2002), Kraft (2006) for the Panzar and Rosse test and Suominen (1994), Berg and Kim (1998), Neven and Röller (1999), for the Bresnahan model. For an extensive literature review see Degryse and Ongena (2005).

${ }^{5}$ See Reiss and Wolak (2005) for more details about the problems with the CV approach.
} 
Dick (2002), is the first paper to apply a structural, multinomial logit demand model ${ }^{6}$ on retail deposit services using data on U.S. commercial banks. Nakane et al. (2006) extend it by studying the market power on the supply side in the Brazilian retail banking. This discrete-choice framework avoids the above mentioned problems of earlier approaches. It models the product differentiation explicitly and helps to overcome the difficulty of estimating a large number of substitution parameters given several banks on the market. In this model, one can analyze market power, consumer preferences and welfare that are not feasible under the other approaches of the empirical banking literature. ${ }^{7}$

We extend Dick's model in three ways. First, we study different loan and deposit services markets separately and we allow the potential market size to change over time and across markets. Second, our definitions of products and markets differ from Dick (2002). ${ }^{8}$ Third, similarly to Nevo (2001) and Nakane et al. (2006), we also estimate PCMs under different supply-side assumptions and test which model fits the data better. We extend Nakane et al. (2006) first, by considering a nested-logit specification that allows the consumers' tastes to be correlated across banks (although still in a restricted way.) This results in somewhat more reasonable substitution patterns. Second, unlike Nakane et al. (2006), we estimate marginal costs with a translog cost function on accounting data. Finally, we conduct several robustness checks. We try to control for credit risks and inflation.

The results of our demand estimates indicate that in all markets consumers react to interest rates and to a lesser extent to services fees. They prefer well-staffed and extensive branch systems. The estimated cost function seems to fit the data well and the estimated marginal cost seems to be intuitive. The "observed" PCMs, calculated with observed interest rates and estimated marginal costs, are high in all loans and in the demand deposit sub-markets. As we compare them to the theoretically implied PCMs we find that on the overdraft, higher purchase loan ${ }^{9}$, personal loan, demand deposit and short-run deposit markets most of the "observed" PCMs are higher than our non-collusive benchmark. At the same time the long term deposit market could be characterized as fairly similar to or below the non-collusive benchmark. We perform several robustness checks and find that the results, other than on the overdraft market, are rather robust. On the overdraft market if we control for the riskiness of consumer or for inflation the "observed" PCMs are more likely to be below the non-collusive one but on the other loan markets the results are unchanged. These finding would imply that the retail banking sector in Hungary behaves fairly collusively. However, other factors may also explain the high margins. The most important ones are switching costs, marketing activity, habit formation, risk factors, competition in credit standards and conditions. Further research is necessary to determine whether collusion or any of these factors are responsible for the large price-cost margins in the Hungarian banking sector.

The rest of the paper is organized as follows. Section 2 describes shortly the Hungarian commercial banking sector. The model is presented in section 3. Section 4 discusses the estimation strategy along with our identifying assumptions. We discuss characteristics of the data in section 5 and present the results of the demand estimation in section 6 . In section 7, we discuss the estimation of a translog cost function and calculate implied and "observed" price cost margins. In section 8 , robustness of our results are tested. Section 9 concludes.

\footnotetext{
${ }^{6}$ As developed by Berry (1994). The precursory papers include McFadden $(1973,1978,1981$.

${ }^{7}$ This is particularly important from a policy perspective (i.e. merger control, see e.g. Ivaldi and Verboven, 2005), where a more complete structural framework might be needed to determine proper regulation.

${ }^{8}$ In Dick (2002) the product is an average dollar deposits, while market share is defined as the number of average deposit accounts at a given metropolitan area. We calculate market shares from the aggregate deposit and loan amounts in commercial banks nationwide and define the market as the deposit and loan amounts in all financial institutions.

${ }^{9}$ Higher purchase loan is defined as unsecured loan for purchase of durable goods.
} 


\section{The Hungarian banking industry}

In Hungary, as in other financial systems in the early stages of development, the commercial banking sector represents the most important part of the financial intermediation. Its effective functioning is particularly important in the facilitation a smooth and efficient reallocation of financial resources from savers to investors. In the 1990s, the Hungarian banking system went through a thorough transformation from a state-owned and money-losing monopoly to an almost fully privatized, highly profitable financial sector. ${ }^{10}$ Financial market liberalization as well as privatization laid the foundations of the modern financial institutional system. Hungary was the first country among the ex-socialist European countries to open the banking market to foreign strategic investors. Initially, the government recapitalized the state banks. It quickly became obvious that recapitalization only enhanced the problems caused by soft budget constraints and moral hazard. In order to improve corporate governance of banks and decrease fiscal costs of recapitalizations, from 1994 the banks were sold to strategic foreign investors. Privatization was completed by the end of 1997 when all large banks were controlled by foreign owners. The only exception was OTP (Országos Takarékpénztár), the largest Hungarian savings bank, that was sold through a public offering on the stock exchange, without a single majority owner. As of end-2005, foreign ownership of Hungarian banks exceeded 80 per cent of total banking capital. This time period can be characterized as one of relatively high GDP growth, steadily decreasing inflation and increasing consumer wealth (Table 3 presents macroeconomic and financial sector-related indicators for 2001-2005).

\section{Accounting profitability}

The Hungarian banking system is very profitable. Since the beginning of 2001 the ROE of the banking sector has increased from around 20 to 30 per cent, while ROA grew from 1.6 per cent to 2.5 per cent. Factors behind this marked improvement in profitability may include a rise in interest earnings arising from stronger retail lending activity, a considerable increase in income from fees and commissions and improved cost-efficiency. Due to the exceptionally high profits of the banking sector temporarily the government levied a special banking tax in 2004 . However, it had only a moderate effect on the profit of the banking system in 2005.

Most of the pre-tax profit of financial institutions still consists of interest income. The net interest margin remained stable at around 4 per cent in 2001 and 2005 mainly due to the generous state interest subsidies on mortgage lending and portfolio restructuring (Table 3). Declining profitability in the corporate business urged banks to shift focus. Several banks have decided to pursue a more aggressive strategy in the retail market. Banks with higher-than-average interest margins are still typically institutions that deal with consumer lending, housing loans and household deposits.

\section{Concentration}

In the first half of 1990s, privatization and recapitalization of state-owned banks and several new entries promoted the break-up of the initial monopolistic market structure. In the second half of the 1990s, mergers and acquisitions as well as numerous bank liquidations suspended the falling concentration of the banking system and stabilized the oligopolistic market structure. ${ }^{11}$

The value of the Herfindhal index calculated on total assets is around 800 but this aggregate indicator hides the differences across the sub-markets, namely, between the corporate and household business line ${ }^{12}$. The degree of concentration in corporate lending and deposit market can be considered low (700-800 in previous years). On the contrary, the concentration is high, above 2000, for both household loans and deposits.

\footnotetext{
${ }^{10}$ The non-bank financial intermediaries and financial markets also experienced a dynamic development in the past decade, but their role in financial intermediation is still narrow.

${ }^{11}$ The second largest bank, K\&H Bank was created in 2001 by the merger of KBC-owned K\&H (Kereskedelmi és Hitel) Bank and ABN Amro Magyar Bank. The third largest, MKB (Magyar Külkereskedelmi Bank) was created by MKB's takeover of Konzum Bank in 2004. In October 2003, Postabank (the second-largest retail bank) was sold to Erste Bank (of Austria), already present in Hungary.

${ }^{12}$ In the U.S., the Department of Justice's Merger Guideline defines the threshold of a highly concentrated market at 1800.
} 


\section{MAGYAR NEMZETI BANK}

Within the household credit, concentration is very high both on the markets of housing and of consumer loans (Table 4) Consumer loans, particularly the markets of overdraft, higher purchase and personal loans are characterized by high concentration. In other consumer lending sub-markets, such as car purchase loans and mortgage loans with general purpose the banking industry is less concentrated.

The household deposit market is also highly concentrated. One bank (OTP) accounts for a large share of domestic deposits. The OTP was the sole nation-wide banking entity, which provided retail deposits and loans for almost 40 years before the establishment of two-tier banking sector (1987). Due to this first-mover advantage, strong financial lobby power as well as the improving management, this bank succeeded to retain its dominant role in retail market. Over the past 10 years the share of this bank is slowly declining: the percentage of domestic retail deposits at the OTP dropped from about 72 to 40 per cent between 1995 and 2005. Parallel to this, the concentration index for household deposit market declined from 2400 to 2100 (Table 4). 


\section{Model}

The demand model described here follows Dick (2002). She estimates demand for deposit services of commercial banks using the standard methodology in the discrete choice literature (see Berry; 1994). We extend her analysis to the deposit submarkets and consumer loan markets. Moreover we also model the supply side. We consider two models of the banking industry: a static, differentiated product Nash-Bertrand oligopoly and a cartel. For each supply model the pricing decisions of the banks depend on the individual bank-level demands. We use the estimated price elasticities to calculate price-cost margins implied by the two supply models.

The simplicity and parsimony of the discrete choice models come at some cost, as such models cannot easily incorporate purchase of multiple goods and dynamic aspects of demand. ${ }^{13}$ Additional drawback of our approach is that product characteristics are treated as exogenous variables. Given that banks, at least in the long-run, choose their product-characteristics, this assumption could be unreasonable ${ }^{14}$. On the supply side we do not consider price discrimination, risks and rationing which could be important at the loan markets. In Hungary, at this time period, for the particular loan products we studied, price discrimination and rationing are probably not that important. In our empirical application, we consider the effect of the banks' portfolio risk on the observed interest rates. We assume the risk is exogenous and adjust our observed loan interest rates with it.

\subsection{DEMAND FOR DEPOSIT SERVICES AND LOANS}

On the demand side, we assume that consumers have already solved their dynamic long-term savings problem and the only decision they make at this point is to choose a bank. So we treat and derive demand function for each of our six products separately. First, we consider a multinomial logit demand specifications for deposit services. Assume that there are $i=1, \ldots, l_{t}$ consumers interested in purchasing deposit services from a bank. There are $j=0,1, \ldots . J_{t}$ banks and $t=1, \ldots T$ time period. $j=0$ indicates the outside option, which is defined as the total households' savings minus the deposits in the commercial bank sector. Let each consumer's utility function be linear such that the conditional indirect utility of consumer $i$ from choosing bank $j$ 's services is:

$$
u_{i j t}^{d}=\delta_{j t}^{d}+\varepsilon_{i j t}=r_{j t}^{d} \alpha^{d}-r_{j t}^{s d} \alpha^{s}+x_{j t} \beta^{d}+\xi_{j t}^{d}+\varepsilon_{i j t},
$$

where $r_{j t}^{d}$ and $r_{j t}^{s d}$ represent interest rates paid by banks on deposits and fees on deposits respectively, $x_{j t}$ is a $K$ dimensional vector of observed bank characteristics other than interest rates, $\xi_{j t}$ represents bank characteristics unobserved to the econometrician (depicted as mean across consumers and independent across banks), $\varepsilon_{i j t}$ is a random disturbance with zero mean, identically and independently distributed across consumers and choices, and $\theta_{D}=\left(\alpha^{d}, \alpha^{s}, \beta^{d}\right)$ is the $K+2$ dimensional vector of mean level of taste parameters to be estimated. Note that the parameters of the utility function do not depend on individual i 's characteristics. We assume that variation in consumers' taste enters only through the additive term, $\varepsilon_{i j t}$. Consumers maximize their utility and choose bank $j$ whenever it gives them the highest utility, i.e. $U\left(r_{j}^{d}, r_{j}^{s d}, x_{j}, \xi_{j}, z_{i}, \theta_{D}\right) \geq U\left(r_{1}^{d}, r_{l}^{s d}, x_{l}, \xi_{l}, z_{i}, \theta_{D}\right)$ for all $I \neq j$, where $z_{i}$ captures consumer specific terms that are not observed by the econometrician. Bank's pricing decision is based on the bank's expectation about its demand:

$$
s_{j t}^{d}=\sum_{i=1}^{I_{t}} E\left(U\left(r_{j t}^{d}, r_{j t}^{s d}, x_{j t}, \xi_{j t}, z_{i t} ; \theta_{D}\right) \geq \max _{l \neq j} U\left(r_{l t}^{d}, r_{l t}^{s d}, x_{l t}, \xi_{l t}, z_{i t} ; \theta_{D}\right)\right)
$$

\footnotetext{
${ }^{13}$ In the banking sector the existence of switching costs would require the dynamic modeling of demand and supply. The clients do not choice among banks in each period, causing persistence in the demand. However, the persistence in the demand affects the pricing behavior of banks. In case of high switching costs with an adequate price-setting banks can increase the number of core clients, i.e. "installed base".

${ }^{14} \mathrm{~A}$ solution would require a dynamic model in which not only prices but also product characteristics are determined within the model. We leave this for future research.
} 
In this expression, $E$ is the bank's expectation over the unobservables in $U$. (Here, the bank is assumed to know the size of the market $I_{t}$.) The bank's expected aggregate demand can equivalently be expressed as the sum of banks' probability assessments that consumers will open a deposit at bank $j$ :

$$
s_{j t}^{d}=\sum_{i=1}^{I_{t}} \operatorname{Pr}(i \text { opens a deposit account at bank } j) \text {. }
$$

This expression shows us how banks' uncertainties about their environment (i.e., their uncertainties about consumers tastes) will enter a structural model of competition. Once we adopt a specific, simplifying, although a restrictive logistic probability model for consumers' product choices, the product-level demands simply are sums of consumers' purchase probabilities. The closed form solution of the multinomial logit model is the following:

$$
s_{j t}^{d}\left(\delta_{t}^{d}\right)=\frac{\exp \left(\delta_{j t}^{d}\right)}{\sum_{r=0}^{J} \exp \left(\delta_{r t}^{d}\right)}, \quad j=1, \ldots J .
$$

The consumer loan demand is specified similarly to the deposit services demand. Assume that there are $m=1, \ldots, M_{t}$ consumers interested in borrowing from a bank. Let each consumer's utility function linear such that the conditional indirect utility of consumer $i$ from choosing bank $j$ 's services is

$$
u_{m j t}=\delta_{j t}^{l}+\varepsilon_{m j t}=r_{j t}^{l} \alpha^{l}+r_{j t}^{s l} \alpha^{s l}+x_{j t} \beta^{l}+\xi_{j}^{l}+\varepsilon_{m j t} \text {, }
$$

where $r_{j t}^{\prime}$ and $r_{j t}^{s l}$ represents interest rates paid by consumers on loans and fees on loans respectively, and the other variables defined as in equation (1). The closed form solution of the multinomial logit model is the following:

$$
s_{j t}^{l}\left(\delta_{t}^{l}\right)=\frac{\exp \left(\delta_{j t}^{l}\right)}{\sum_{r=0}^{J} \exp \left(\delta_{r t}^{l}\right)}, \quad j=1, \ldots J .
$$

\subsection{SUPPLY OF DEPOSIT SERVICES AND LOANS}

We consider two models of competition on the supply side. In our supply models, similarly to the earlier papers, we assume that banks maximize their profit separately in each sub-market and that the interbank market is perfectly competitive. The separate profit maximization could be a fairly restrictive assumption since banks very often bundle their products. Bundling and other unobserved (by us) switching costs probably make the demand less elastic to interest rate changes. This increases the PCMs implied by our differentiated product Nash-Bertrand model meaning that even our non-collusive benchmark model is less competitive.

First, we derive first-order conditions in a differentiated product Bertrand model. Second, we derive first-order conditions for a cartel. Assume that there are $J$ profit-maximizing banks choosing interest rates and fees to maximize their profits both on the deposit and on the loan markets separately (i.e. no bundling) under liquidity constraint. The profit function of each bank is the following:

$$
\begin{aligned}
& \operatorname{Max}_{r_{j t}^{s d}, r_{j t}^{d}, r_{j t}^{l}, r_{j t}^{s l}} \pi \pi_{j}=\left(r_{j t}^{s d}-r_{j t}^{d}\right) I_{t} s_{j t}^{d}\left(\delta^{d}\right)+\left(r_{j t}^{l}+r_{j t}^{s l}\right) M_{t} s_{j t}^{l}\left(\delta^{l}\right)-C_{j t}\left(I_{t} s_{j t}^{d}\left(\delta^{d}\right), M_{t} s_{j t}^{l}\left(\delta^{l}\right)\right)+R_{j t} r_{t}, \\
& \text { s.t. } I_{t} s_{j t}^{d}\left(\delta^{d}\right)=M_{t} s_{j t}^{l}\left(\delta^{l}\right)+R_{j t}
\end{aligned}
$$

where $R_{j t}$ is the net interbank exposure at $r_{t}$ interest rate. $I_{t}$ and $M_{t}$ are the deposit and loan market size. The profit function consist of the revenue from the deposit markets, the revenue from the loan markets, minus the cost $\left(C_{j t}\right)$, and finally a net balance of interbank actions. The balance sheet constraint states that the total deposit amounts should be equal to the total loan amount plus the net interbank exposure. We assume that the interbank market is perfectly competitive and banks can borrow and lend at the same interest rate $r_{t}$. The cost function consists of non-interest costs such as wages and capital costs. After substituting the constraints: 


$$
\begin{aligned}
\pi_{j}= & \left(r_{j t}^{s d}-r_{j t}^{d}\right) I_{t} s_{j t}^{d}\left(\delta^{d}\right)+\left(r_{j t}^{l}+r_{j t}^{s l}\right) M_{t} s_{j t}^{l}\left(\delta^{l}\right) \\
& -C_{j t}\left(I_{t} s_{j t}^{d}\left(\delta^{d}\right) M_{t} s_{j t}^{l}\left(\delta^{l}\right)\right)+\left(I_{t} s_{j t}^{d}\left(\delta^{d}\right)-M_{t} s_{j t}^{l}\left(\delta^{l}\right)\right) r_{t} .
\end{aligned}
$$

We assume that deposit interest rates have no effect on the loan market share and vice versa. The first-order conditions for bank $j$ are the following:

$$
\begin{aligned}
& \left(r_{j t}^{s d}-r_{j t}^{d}+r_{t}-c_{j t}^{d}\right)=\frac{s_{j t}^{d}\left(\delta^{d}\right)}{\frac{\partial s_{j t}^{d}\left(\delta^{d}\right)}{\partial r_{j t}^{d}},} \\
& \left(r_{j t}^{s d}-r_{j t}^{d}+r_{t}-c_{j t}^{d}\right)=-\frac{s_{j t}^{d}\left(\delta^{d}\right)}{\frac{\partial s_{j t}^{d}\left(\delta^{d}\right)}{\partial r_{j t}^{s d}}}, \\
& \left(r_{j t}^{l}+r_{j t}^{s l}-r_{t}-c_{j t}^{l}\right)=-\frac{s_{j t}^{l}\left(\delta^{l}\right)}{\frac{\partial s_{j t}^{l}\left(\delta^{l}\right)}{\partial r_{j t}^{l}}}, \\
& \left(r_{j t}^{s l}+r_{j t}^{l}-r_{t}-c_{j t}^{l}\right)=-\frac{s_{j t}^{l}\left(\delta^{l}\right)}{\frac{\partial s_{j t}^{l}\left(\delta^{\prime}\right)}{\partial r_{j t}^{l l}}} .
\end{aligned}
$$

The first-order conditions can be easily transformed to the familiar Lerner-indeces by dividing both sides with the appropriate interest rate or service fee. The Lerner-index states that the marginal revenue minus the marginal cost of the banks $\left(c_{j t}\right)$, divided by the price should be equal to the residual demand elasticities. In our case the marginal revenue on deposits is equal to the sum of service fee and interbank interest rate. The marginal cost is equal to the paid interest rate plus the non-interest marginal cost. On loans the marginal revenue is the sum of the charged interest rate and service fees. The marginal cost is the sum of interbank interest rate and non-interest marginal costs.

In case of cartel the banks maximize their joint profit. The profit function is the sum of the individual banks' profit.

$$
\begin{gathered}
\operatorname{Max}_{r_{j t}^{s d}, r_{j t}^{d}, r_{j t}^{l}, r_{j t}^{s l} j=1, \ldots j} \sum_{j=1}^{J} \pi_{j}=\sum_{j=1}^{J}\left(\begin{array}{c}
\left(r_{j t}^{s d}-r_{j t}^{d}\right) I_{t} s_{j t}^{d}\left(\delta^{d}\right)+\left(r_{j t}^{l}+r_{j t}^{s l}\right) M_{t} s_{j t}^{l}\left(\delta^{l}\right) \\
-C_{j t}\left(I_{t} s_{j t}^{d}\left(\delta^{d}\right), M_{t} s_{j t}^{l}\left(\delta^{l}\right)\right)+R_{j t} r_{t}
\end{array}\right) \\
\text { s.t. } \quad I_{t} s_{j t}^{d}\left(\delta^{d}\right)=M_{t} s_{j t}^{l}\left(\delta^{l}\right)+R_{j t} \text { for every } j
\end{gathered}
$$

where $R_{j t}$ is the net interbank exposure at $r_{t}$ interest rate. $I_{t}$ and $M_{t}$ are the deposit and loan market size. After substituting the constraints we get the following:

$$
\pi_{j}=\sum_{j=1}^{J}\left(\begin{array}{c}
\left.\left(r_{j t}^{s d}-r_{j t}^{d}\right) I_{t} s_{j t}^{d}\left(\delta^{d}\right)+\left(r_{j t}^{l}+r_{j t}^{s l}\right) M_{t} s_{j t}^{l}\left(\delta^{l}\right)-C_{j t}\left(I_{t} s_{j t}^{d}\left(\delta^{d}\right), M_{t} s_{j t}^{l}\left(\delta^{l}\right)\right)\right) \\
+\left(I_{t} s_{j t}^{d}\left(\delta^{d}\right)-M_{t} s_{j t}^{l}\left(\delta^{l}\right)\right) r_{t}
\end{array}\right) .
$$


The first-order conditions for bank $j$ :

$$
\begin{aligned}
& \left(r_{j t}^{s d}-r_{j t}^{d}+r_{t}-c_{j t}^{d}\right)=\frac{s_{j t}^{d}\left(\delta^{d}\right)}{\frac{\partial s_{j t}^{d}\left(\delta^{d}\right)}{\partial r_{j t}^{d}}}-\sum_{k \neq j}\left(r_{k t}^{s d}-r_{k t}^{d}+r_{t}-c_{k t}^{d}\right) \frac{\frac{\partial s_{k t}^{d}\left(\delta^{d}\right)}{\partial r_{j t}^{d}}}{\frac{\partial s_{j t}^{d}\left(\delta^{d}\right)}{\partial r_{j t}^{d}}}, \\
& \left(r_{j t}^{s d}-r_{j t}^{d}+r_{t}-c_{j t}^{d}\right)=-\frac{s_{j t}^{d}\left(\delta^{d}\right)}{\frac{\partial s_{j t}^{d}\left(\delta^{d}\right)}{\partial r_{j t}^{s d}}}-\sum_{k \neq j}\left(r_{k t}^{s d}-r_{k t}^{d}+r_{t}-c_{k t}^{d}\right) \frac{\frac{\partial s_{k t}^{d}\left(\delta^{d}\right)}{\partial r_{j t}^{s d}}}{\frac{\partial s_{j t}^{d}\left(\delta^{d}\right)}{\partial r_{j t}^{s d}}}, \\
& \left(r_{j t}^{s l}+r_{j t}^{l}-r_{t}-c_{j t}^{l}\right)=-\frac{s_{j t}^{l}\left(\delta^{l}\right)}{\frac{\partial s_{j t}^{l}\left(\delta^{l}\right)}{\partial r_{j t}^{l}}}-\sum_{k \neq j}\left(r_{k t}^{s l}+r_{k t}^{l}-r_{t}-c_{k t}^{l}\right) \frac{\frac{\partial s_{k t}^{l}\left(\delta^{\prime}\right)}{\partial r_{j t}^{l}}}{\frac{\partial s_{j t}^{l}\left(\delta^{\prime}\right)}{\partial r_{j t}^{l}}}, \\
& \left(r_{j t}^{s l}+r_{j t}^{l}-r_{t}-c_{j t}^{l}\right)=-\frac{s_{j t}^{l}\left(\delta^{l}\right)}{\frac{\partial s_{j t}^{l}\left(\delta^{\prime}\right)}{\partial r_{j t}^{s l}}}-\sum_{k \neq j}\left(r_{k t}^{s l}+r_{k t}^{l}-r_{t}-c_{k t}^{l}\right) \frac{\frac{\partial s_{k t}^{l}\left(\delta^{\prime}\right)}{\partial r_{j t}^{l l}}}{\frac{\partial s_{j t}^{l}\left(\delta^{\prime}\right)}{\partial r_{j t}^{l l}}} .
\end{aligned}
$$

In a collusive equilibrium the profit-maximizing banks internalize the negative business stealing effect they have on other banks and charge a higher price (higher/lower interest rates in case of loans/deposits.) In the next sections we estimate demand functions for deposit services and loans and calculate the corresponding elasticities. We estimate the marginal cost functions of individual banks for each product. Using the first-order conditions derived above we then make inferences about which model of competition fits the data better. 


\section{Demand estimation}

The usual problem in estimating a market demand model in a differentiated products industry is that prices are correlated with the unobserved demand factors (such as style or service quality). This endogeneity problem results in biased parameter estimates. It has been documented in the literature that ignoring this correlation may even lead to upward sloping demand curves (Berry, 1994; Berry et al., 1995). In this paper we rely on the approach developed by Berry (1994) that takes a discrete choice model context as a starting point. The obvious remedy for this endogeneity problem is to use instrumental variables. In such a discrete choice setting prices and the unobserved product characteristics enter demand equations in a nonlinear way that makes the application of instrumental variables method cumbersome. Berry (1994) proposes an estimation procedure, which avoids this problem by transforming the equation so that the parameters enter the objective function linearly.

\section{Logit specification}

Let $S_{j t}^{d}$ and $S_{j t}^{\prime}$ be the observed market shares of bank $j$ in time period $t$ on the demand and loan markets and $s_{j t}^{d}$ and $s_{j t}^{\prime}$ the predicted market shares from the model. We treat actual sales, $q_{j t}$, as a realization from the demand curve that the bank uses to set its price. We assume that the distribution of the consumer variables is the same for each of the $I_{t}$ and $M_{t}$ consumers in the deposit and loan markets, respectively. Then we can replace the household-specific probabilities $\operatorname{Pr}\left(r_{j}^{d}, r_{j}^{s d}, x_{j}, \xi_{j}, z_{i}, \theta_{D}\right)$ with unconditional purchase probabilities. At the true value of mean utility levels $\left(\delta_{t}\right)$ the following equations hold:

$$
S_{j t}^{d}=I_{t} s_{j t}^{d}\left(\delta_{t}^{d}\right) \text { and } S_{j t}^{l}=M_{t} s_{j t}^{l}\left(\delta_{t}^{l}\right)
$$

In the case of the logit model one can solve analytically for the mean utility levels. Otherwise numerical solutions are necessary. The mean utility level will be uniquely determined by the observed market shares.

The standard logit demand equation will have the following form for deposit supply (normalizing the mean utility of the Oth outside good to zero):

$$
\ln \left(S_{j t}^{d}\right)-\ln \left(S_{0 t}^{d}\right)=\delta_{j t}^{d}=r_{j t}^{d} \alpha^{d}-r_{j t}^{s d} \alpha^{s d}+x_{j t} \beta^{d}+\xi_{j t}^{d},
$$

and for loan demand:

$$
\ln \left(S_{j t}^{l}\right)-\ln \left(S_{0 t}^{l}\right)=\delta_{j t}^{l}=r_{j t}^{l} \alpha^{l}+r_{j t}^{s l} \alpha^{s l}+x_{j t} \beta^{l}+\xi_{j t}^{l}
$$

One can estimate these equations by a simple ordinary least square regressions. The interest rates are potentially endogenous but a standard linear instrumental variable method can be used to avoid this problem. We calculate corresponding own price elasticities of bank $j$ in period $t$, according to the following formula that can be easily derived from equations ( 1 and 2 ). The deposit rate elasticity is

$$
\eta_{j k t}^{d}=\frac{\partial s_{j t}^{d}}{\partial r_{k t}^{d}} \frac{r_{k t}^{d}}{s_{j t}^{d}}=\left\{\begin{array}{cc}
\alpha^{d} r_{j t}^{d}\left(1-s_{j t}^{d}\right) & \text { if } j=k \\
-\alpha^{d} r_{k t}^{d} s_{k t}^{d} & \text { if } j \neq k
\end{array},\right.
$$

and the service fee elasticity can be calculated as:

$$
\eta_{j k t}^{d s}=-\frac{\partial s_{j t}^{d}}{\partial r_{k t}^{s d}} \frac{r_{k t}^{s d}}{s_{j t}^{d}}=\left\{\begin{array}{ll}
\alpha^{s d} r_{k t}^{s d}\left(1-s_{j t}^{d}\right) & \text { if } j=k \\
-\alpha^{s d} r_{k t}^{s d} s_{k t}^{s d} & \text { if } j \neq k
\end{array} .\right.
$$


Loan rate elasticities are calculated correspondingly. Estimates of the price-cost margins can be obtained by a simple calculation from the estimated deposit service and loan demand parameters.

\section{Nested logit specification}

The simple logit model has the so-called independence of irrelevant alternatives property when only aggregate data are available and very restrictive substitution patterns. The model implies that if two products have the same market share then they have the same cross-price elasticities and the same markups. To mitigate this problem we consider a nested logit specification. This requires an a priori grouping of banks that are believed to be correlated with respect to consumer preferences over them. In this case, a priori grouping of banks limit the problem of restrictive substitution to products within the group. The estimated equation will become the following (see Berry, 1994):

$$
\ln \left(S_{j t}^{d}\right)-\ln \left(S_{0 t}^{d}\right)=\delta_{j t}^{d}=r_{j t}^{d} \alpha^{d}-r_{j t}^{s d} \alpha^{s}+x_{j t} \beta^{d}+\sigma \ln \left(-_{d}^{d} s_{j t}\right)+\xi_{j t},
$$

where $\bar{s}_{j / g t}^{d}$ represents the market share of deposit product $j$ which belongs to group $g$ as a fraction of the total group share at time $t$. This term is also endogenous and instrumental variables are necessary to obtain consistent estimates.

The implied own- and cross-price elasticities for the deposit interest rates are:

$$
\begin{gathered}
\varepsilon_{j j t}^{d}=\frac{\partial s_{j t}^{d}\left(\delta^{d}\right)}{\partial r_{j t}^{d}} \frac{r_{j t}^{d}}{s_{j t}^{d}\left(\delta^{d}\right)}=-\frac{1}{1-\sigma} r_{j t}^{d} \alpha^{d}\left(\sigma s_{j / g t}+(1-\sigma) s_{j t}^{d}-1\right), \\
\varepsilon_{j k t}^{d}=-\frac{\partial s_{j t}^{d}\left(\delta^{d}\right)}{\partial r_{k t}^{d}} \frac{r_{k t}^{d}}{s_{j t}^{d}\left(\delta^{d}\right)}=\left\{\begin{array}{ll}
\frac{1}{1-\sigma} r_{k t}^{d} \alpha^{d}\left(\sigma s_{j / g t}^{d}+(1-\sigma) s_{k t}^{d}\right) & \text { if } j \neq k \text { and } k \in g \\
r_{k t}^{d} \alpha^{d} s_{k t}^{d} & \text { if } j \neq k \text { and } k \notin g
\end{array},\right.
\end{gathered}
$$

where $\sigma$ is the within group correlation of utility levels. These elasticities refer to the percentage change in market share in response to a change in price. The cross-price elasticity between product $j$ and product $k$ located in a different group $g$ is independent of $j^{15}$

\footnotetext{
${ }^{15}$ The elasticities for credit interest rates can be calculated in a similar way.
} 


\section{Data and variables}

We covered six retail sub-markets, three on the lending (overdraft, higher purchase and personal loans) and three on the deposit sides (demand, short-term and long-term deposits. ${ }^{16}$ Monthly data for the period of January 2003-December 2005 were used for the empirical analysis, except for higher purchase and personal loan markets, where data were available only for May 2004-December 2005. In case of higher purchase and personal loan markets we employed annual charge (APRC) calculated on new Hungarian forint (HUF) credit as a proxy for price, which includes not only the interest rate but also the additional fees and commissions. In other market segments the interest rates calculated on the existing stock of HUF credit or deposit were available only. The service fee for deposit market is approximated by the ratio of revenue from fees and commissions ${ }^{17}$ to the stock of deposits. The market share was proxied by the stock of credit or deposit amounts at the end of a month by a certain bank in percentage of the whole market size in all market segments separately.

We choose the bank attributes based on the availability and reliability of data and their importance and observability to the consumers. Table 5 describes the summary statistics of our variables. Most of the available data measure observed bank characteristics at the national market level so in every given time period we observe only a single market in each product category. Due to the changing structure of the banking-sector the number of banks in the cross-sections might vary over time and across different sub-markets.

The data is collected from several sources. Bank characteristics information are from the Hungarian Financial Supervisors Authority, from the National Bank of Hungary and from the websites of the banks. Banks are obliged to report balance sheet and income statement information every month to the Hungarian FSA and are asked to provide data on further bank characteristics (such as number of branches, number of employees).

\section{Capturing heterogeneity and product differentiation}

The products in our analysis are deposit services and loans. The differentiating factors are the different characteristics of banks. We have a few characteristics of banks that we can observe. We used the number of branches as a proxy of spatial differentiation and average number of employees in a branch as a proxy for service quality. We calculated an age variable (that can capture some aspect of reputation, reliability, experience) based on the establishment date of the banks. We define three groups based on the total assets of banks: small banks (that we choose as a reference group), medium-size banks (Medium), and a large bank (Big) that is OTP.

\section{Defining relevant market}

We define the market as the total household deposits and total consumer loans (excluding loans for vehicle purchase) denominated in HUF in all monetary financial institutions (MFIs) in Hungary and calculate market shares from the deposit and loan amounts in commercial banks nationwide. Other monetary financial institutions (such as thrifts and credit unions) constitute the outside good in our demand model. Our choice of the market and therefore of the outside good was driven by two main facts. First, we used only HUF stocks since foreign exchange consumer lending (excluding loans for vehicle purchase) and borrowing were limited in our time period. Second, we used data of MFls because of data limitations but non-MFIs played limited role in financial intermediation on the investigated sub-markets. ${ }^{18}$

\footnotetext{
${ }^{16}$ We do not cover the mortage lending for two reasons: due to the lack of market pricing in Hungarian forint mortgage lending (interest rates are determined by state subsidy scheme) and due to the short sample period of foreign currency denominated mortgage lending.

${ }^{17}$ Fees and commissions can steam from lending activity also.

${ }^{18}$ Note that if we defined the market in a broader way, we would probably obtain higher price elasticities, i.e. lower price-cost margins in both hypothetical cases. As the observed margins would stay unchanged, this would shift our overall conclusion towards less competitive markets.
} 


\section{Creating nests}

According to the main characteristics of Hungarian banks' retail activity several groups of alternatives, i.e. nesting levels can be formed. The first nest includes only one bank called OTP, which is the largest one in Hungary. The separation of OTP can be explained by its history. The OTP was the sole nation-wide banking entity, which provided retail deposits and loans for almost 40 years before the establishment of two-tier banking sector (1987). Due to this significant competitive edge, strong financial lobby power as well as the improving management ability this bank succeeded to retain its dominant role in retail market until now. In the second nest, the medium size universal banks can be found, which strongly compete with each other for the retail clients. After the consolidation and restructuring of Hungarian banking sector (1992-1995) this group of banking entities experienced several market entries and M\&A's leading to improving cost efficiency and profitability. The rest consists of small banks that have very limited market activity or focus only on one niche market, e.g. act as a mediator in promoting nationality based economic, financial and trade relations or offer specialized products and services. These banks are collected in the third nest.

\section{Choice of instruments}

Unobserved bank characteristics, such as service quality, reputation, credit conditions other than interest rates, experience may capture some aspect of soundness of an institution for consumers and therefore, influence consumers' decision. Such characteristics may also be correlated with prices and make them endogenous. To avoid the endogeneity bias we opt for using instrumental variables (IV) estimation. Dick (2002) lists several possibilities (which she calls cost shifters) from which we use a measure for credit risk $^{19}$, capital adequacy ratio, the ratio of liquid assets to total assets, operational cost per deposits, share of loans per total assets, and the average salary per capita of other banks ${ }^{20}$ in a period. These variables, while having some influence on the cost of the products, are likely to be exogenous to the pricing decisions of the banks.

In addition to the cost shifters, a common practise in the discrete choice literature (based on Berry et al., 1995) is to use the characteristics of other products in the market as instruments for price. The literature refer to them as BLP instruments and we keep this notation throughout the paper. In the nested logit specification $\left(\bar{s}_{j / g}^{d}\right)$ is also likely to be correlated with the unobserved bank characteristics and therefore needs to be instrumented. We use BLP-type of instruments again, namely, we use the characteristics of other banks in a nest group for the within market share of a given bank.

We employ time dummies to capture the changes in the economy that can be considered to have a non bank-specific effect on consumer choice. These non bank-specific effects include changes in consumer wealth, changes in regulations that affect the deposit base of each banks.

\footnotetext{
${ }^{19}$ Credit risk is related to cost of loans, at the same time, banks may cross-subsidize them by shifting some of their cost towards other products.

${ }^{20}$ The average salary in a bank may be correlated with service quality since employees are more motivated or because the higher salary is likely to attract more qualified workers.
} 


\section{Results of demand estimations}

As we discussed before, the logit and nested logit specifications can be estimated by regressing the logarithms of observed market shares $\left(\ln \left(S_{j t}^{d}\right)-\ln \left(S_{o t}^{d}\right)\right)$ on prices, other product characteristics and time dummies. Table 6 and Table 7 display the results of 2SLS estimation using cost shifters and BLP instruments for logit as well as nested logit specifications respectively. The columns of the tables refer to the consumer lending sub-markets, such as overdraft, higher purchase loans, personal loans and to the household deposit sub-markets, such as demand, short-term, and long-term deposits. The first set of rows show the coefficients of explanatory variables, then the calculated elasticities can be found, finally the characteristics of estimations are presented.

According to the $R^{2}$ and $F$-statistics the fit of first stage regressions can be considered good in all cases. The first stage regressions with regard to the nest variable show reasonably good fit as well. These suggest that our instruments are sufficiently correlated with the endogenous interest rate variables. Overidentification tests are accepted in almost all cases at one per cent significance level. The test is rejected only for the market of higher purchase loan in logit specification. In the following, we investigate the estimation results of logit and nested logit specification in more detail (Table 6 and Table 7).

\subsection{CONSUMER LOANS}

On the consumer lending sub-markets, we find a negative relationship between price and market share. All coefficients of price variables were significant and negative in both the logit and nested logit estimations. In the nested logit specification lower coefficients of consumer loans were found. Note, however, that, our nested logit model of the higher purchase loans appears to be misspecified since the parameter of nest variable does not significantly differ from zero. ${ }^{21}$ The correlation parameters of other consumer lending sub-markets appear to be close to one, indicating that consumer preferences across banks in the same nests are highly correlated.

According to our estimation results, the number of branches variable has a positive impact on the demand of loans. ${ }^{22}$ Both specifications share this feature, the coefficients are always highly significant. The employees per branch variable is also significant with a positive sign in the majority of cases, except for personal loans in logit specification and overdraft in nested logit specification. The parameters of the age variable (that is a proxy for experience) are positive for higher purchase and personal loans and negative, but insignificant for overdraft in the instrumented logit regressions. Interestingly the big (to which only the largest OTP bank belongs) and medium groups have negative signs in most of the markets other than long-term deposits. OTP as the old socialist monopoly bank is still adjusting to a competitive environment and gradually losing consumers to other, younger rivals. Further explanation might be that the small banks are specialized on the consumer lending and have specific clients with different risk characteristics.

Own price elasticities calculated based on the equations (19) and (22) are all negative and significant. The logit specification results in relatively elastic own price elasticities, -5.4 for overdraft, -4.6 for higher purchase loan and $-5-9$ for personal loan, respectively. The elasticities are similar in size to the estimation of Móré and Nagy (2004) on the aggregated consumer lending market. However, in the case of our nested logit model-specification own price elasticities are more modest in absolute value, in the range of -2.5 (overdraft) and -2.1 (higher purchase loan) near to the theoretical minimum level. ${ }^{23}$ This could indicate that credit conditions (i.e collateral, repayment schedule, etc.) are also very important part of consumers' decision on loans.

\footnotetext{
${ }^{21}$ Low and insignificant coefficient of nest variable means that nest-creation is not appropriate. The low number of observations (around 80 ) could be the reason of misspecification.

${ }^{22}$ In case of higher purchase loan, the products are sold mainly through dealers so here the size of the branch-network is probably a proxy for the number of dealers.

${ }^{23}$ Theoretically, profit-maximizing oligopolistic firms should operate at the elastic part (with price elasticity larger than 1 in absolute value) of the demand curve.
} 


\subsection{HOUSEHOLD DEPOSITS}

The parameters of the deposit rate are positive and significant and the coefficients of the service fees are significant and negative. This suggest that consumers respond to prices and service fees on the deposit market. Parameters of nest variable are always significant and relatively high, suggesting that the creation of nests is appropriate.

In most cases the observed bank characteristics are significant and have the expected sign. The number of branches are found to influence consumers' bank choices significantly and positively. Also, the parameter of the number of employees per branch is mostly positive and significant. The Big dummy is negatively related to the bank demand. The development of branch structure can serve as an explanation. OTP has by far the largest number of branches, but in the last couple years the other banks opened new retail branches to catch up with OTP.

Own price elasticities are around 5 for demand deposit, 8.5 for short-term deposit, and 6.2 for long-term deposit as calculated from the results of logit specification. In case of nested logit specification the elasticities are found in a higher and wider range opposite to the consumer lending markets. Elasticities amount to 10.8 for demand deposit, 19.9 for short-term deposit, 8.2 for long-term deposits, respectively. Móré and Nagy (2004) found that the own-price elasticity of deposit is around 10. However, they investigated deposit on aggregate level, including the borrowings of household, corporate and government sectors. We find in the logit specification, that demands for all types of deposits are inelastic or slightly elastic with respect to service fees. In the logit specification the inelasticity of services fees in case of overdraft and short-term deposit does not suggest profit maximizing behavior of banks in this respect. This finding is similar to Dick's (2002) or Nakane et al. (2006). They argue that banks may use low or zero-fee checking account as loss leaders to attract consumers or higher rates could trigger regulatory intervention. In our case, the service fee was computed and it possibly could also include some service fee on loans which distort the findings. In the nested logit specification the demand is slightly elastic on service fees in all market segments. 


\section{Measuring the degree of competition}

In order to determine which model fits the banking industry, we compute the margins implied by the Bertrand and cartel models and compare them with the estimated "observed" price-cost margins (PCMs.) The PCMs of Bertrand and cartel cases can be calculated from the right hand-side of the first-order conditions, described by equations (7), (10) and (13), (16), respectively. The "observed" PCMs can be obtained from the left hand side of the first order conditions, using the observed interest rates and estimates of bank and product specific marginal costs.

We consider an upper and a lower limit on the true marginal costs. First, we assume that marginal costs are zero, which provides a lower limit on the true marginal costs. Second, we derive the marginal costs from an estimated translog cost functions which provides an upper limit since we treat all costs as variable. Since our estimates could be quite noisy we also calculate the marginal cost level which would make the "observed" PCMs consistent with the PCMs implied by the Bertrand model.

\subsection{COST FUNCTION}

Our translog cost function is compatible with the multiple output production of the banks and provides a second-order Taylor series approximation of an arbitrary function at the mean of the data. In our cost model, banks produce two outputs and two inputs. The first output is defined as the production of a bank in a certain sub-market (overdraft, higher purchase loan, personal credit, demand deposit, short-term, long-term deposit, respectively), while the second output is the rest of its total assets. ${ }^{24}$ Inputs consist of labour and physical capital. Labour cost is approximated by the ratio of personal expenses to the number of employees, while the price of physical capital is proxied by the difference between all non-interest and personal expenses to fixed assets. The total cost is therefore the sum of the non-interest expenses. Following Kim (1985) our model consists of the translog cost function and cost share equations for the inputs (Shephard's lemma) as follows:

$$
\begin{aligned}
\ln \left(T C_{j t}\right)= & \lambda+\sum_{n} \tau^{n} \ln Q_{j t}^{n}+\sum_{m} v^{m} \ln P_{j t}^{m}+\frac{1}{2} \sum_{n} \sum_{p} \phi_{n p}\left(\ln Q_{j t}^{n} \ln Q_{j t}^{p}\right) \\
+ & \left(\frac{1}{2}\right) \sum_{m} \sum_{r} \varphi_{m r}\left(\ln P_{j t}^{m} \ln P_{j t}^{r}\right)+\sum_{n} \sum_{m} \chi_{n m} \ln Q_{j t}^{n} \ln P_{j t}^{m}+\eta_{i t}, \\
& S_{j t}^{m}=v^{m}+\sum_{r} \varphi_{m r} \ln P_{j t}^{r}+\sum_{n} \chi_{n m} \ln Q_{j t}^{n}+\vartheta_{i t}^{m}
\end{aligned}
$$

where $T C_{j t}$ corresponds to total costs, $Q_{j t}^{n}$ is the $n^{\text {th }}(n=1.2)$ output, $P_{j t}^{m}$ is the $m^{\text {th }}(m=1.2)$ input price of bank $j$ in time $t, \lambda$ is common constant and $S$ is cost share, i.e. expenditures on input $m$ divided by total cost. Symmetry and linear homogeneity require the following parameter restrictions:

$$
\phi_{n p}=\phi_{p n}, \varphi_{m p}=\varphi_{p m}, \sum_{m} v_{j}^{m}=1, \sum_{r} \varphi_{m r}=0, \sum_{m} \chi_{n m}=0
$$

We allow the correlation of error terms on the cost function and share equations, but we assume the correlation is zero across banks. Since $\ln Q$ is an endogenous variable, we use iterative three-stage least squares and characteristics of rival banks as instruments to estimate the system of three equations.

\footnotetext{
${ }^{24}$ If we would consider more outputs, the number of parameters to be estimated would increase beyond our limited data.
} 
Then the marginal cost function, $c_{j t}^{s}$ (where $s$ stands for the specific product which is always product 1 in the cost function) can be calculated by taking the first order condition of the translog cost function with respect to first output on the sub-market $s$ in the following manner:

$$
c_{j t}^{1}=\frac{T C_{j t}}{Q_{j t}^{1}}\left(\tau^{1}+\phi_{11} \ln Q_{j t}^{1}+\frac{1}{2} \phi_{12} \ln Q_{j t}^{2}+\chi_{11} \ln P_{j t}^{1}+\chi_{12} \ln P_{j t}^{2}\right)
$$

Here we assume that all banks are X-efficient. ${ }^{25}$ Table depicts parameter estimates for cost function. Based on the tstatistics and the value of the adjusted $R^{2}$ the overall fit of the cost equations can be considered very good for all market segments. Standard deviations of individual marginal costs (calculated by the delta method) of bank $j$ in time $t$ are low except for the market of demand deposit, which means that for the majority of sub-markets our "observed" price-cost margins (calculated with observed interest rates and the estimated marginal costs) have low standard errors as well. Table reports the average marginal costs from the cost function estimations and the residual marginal costs that are imputed from our supply models and demand elasticities estimates.

\subsection{RESULTS: “OBSERVED” AND IMPLIED PRICE-COST MARGINS}

Tables 10, 11 and $12^{26}$ show the results for absolute (profit margins) and relative (Lerner-index) price-cost margins, including the means of "observed" margins and the implied margins of Bertrand competition and cartel solution (calculated with the estimated demand elasticities.) For consumer sub-markets means of "observed" Lerner-indeces are for overdraft and around 0.6 for personal and higher purchase loans. The "observed" profit margins are around half of the annual charges (APRC) on the loan markets. The averages of implied Bertrand and cartel PCMs are also high. The "observed" mean PCMs are generally above the implied Bertrand ones except for the overdraft nested-logit case. On the household deposits side, for demand deposit the mean of "observed" PCMs is very high, 8.5. In case of short- and long-term deposits the means of observed PCMs are only 0.13 and 0.17 respectively. Means of implied Bertrand and cartel PCMs are relatively low in all deposit market segments. The "observed" mean PCMs are above the implied Bertrand ones for demand deposits and short-term deposit and below for long-term deposits.

From Table 12 it is apparent that in most of the sub-markets through time the "observed" PCMs are decreasing. This could possibly indicate that through time the commercial banking sector is becoming more and more competitive.

Note that, we cannot provide evidence on the degree of competition based on a simple comparison of mean values as both "observed" values and also predicted Bertrand and cartel PCMs are scattered in a relatively wide range throughout banks and time period as well (Table 11 and 12). Therefore we follow the market power test of Nakane et al. (2006) and compare "observed" and implied margins for each banks. Banks are sorted in three intervals according to their "observed" PCMs: lower than the implied Bertrand value, between Bertrand and cartel value or above cartel value. We define the degree of competition low if the majority of "observed" values are higher than the predicted values of Bertrand model. ${ }^{27}$ Table 13 summarizes the results showing both the frequency and the banks' market share weighted frequency of observations in each interval. The conclusion on the degree of competition is qualitatively the same for the two alternative aggregations.

On the household loan side, the logit results for overdraft, higher purchase and personal loans, indicates that the "observed" price-cost margins are very close to or even above the implied margins of the cartel. In the nested logit case a higher ratio of "observed" margins is under the Bertrand values, but the majority of "observed" margins are still above. On the household deposit side, for demand deposits the logit and the nested models show similar results. The "observed" PCMs are close to the cartel values. In the case of short-term and long-term deposit markets, in the logit specification most of the observed PCMs are below the Bertrand values. In the nested logit specification, however, shortterm deposits turn around and the majority of "observed" margins are above the Bertrand values.

\footnotetext{
${ }^{25}$ Composite errors of the cost function may include (X-)inefficiency terms. Here we assume that every banks are on the cost frontier, i.e. inefficiency terms equal to zero.

${ }^{26}$ For deposit services we report the interest rate PCMs without the service fees. In the next section we include service fees as well (Table 19) The results are similar.

${ }^{27}$ Bertrand and cartel PCMs' confidence intervals of a given bank are overlapped only in few cases.
} 


\section{Table 1}

Degree of competition

\begin{tabular}{ll|c|c}
\hline & & Logit & Nested logit \\
\hline Consumer loans & Overdraft & low & low \\
& Higher purchase loans & low & low \\
& Personal loans & low & low \\
\hline Household deposits & Demand deposits & low & low high \\
& Short-term deposits & high & high \\
& Long-term deposits & high & \\
\hline
\end{tabular}

Note: Degree of competition is considered low if the majority of observed values are higher than the predicted values of Bertrand model. Degree of competition is considered high if the majority of observed values are lower than the predicted values of Bertrand model.

The overall conclusion (Table 1) is that Bertrand model seems to give an accurate description of bank's behavior on the long-term deposits market in both specifications and suggests high degree of competition (i.e. PCMs are relatively low.) However, according to the market power test, Bertrand model does not fit the bank's behavior on the overdraft, higher purchase and personal loans as well as on the demand deposit markets. Moreover, tests indicate that cartel solution characterizes the competition pattern and market power on these markets rather well and the "observed" PCMs are quite high. Our results are inconclusive for the short-term deposits. The logit specification results suggest competitive market behavior of banks, while the nested logit specification results indicate that the degree of competition is rather low. It is also important to mention that the true marginal cost are probably lower than our estimated ones. Of course, under the assumption of zero marginal cost, the "observed" PCMs are much higher (particularly for higher purchase and personal loans as well as for demand deposit,) indicating lower level of competition compared to the results reviewed previously. 


\section{Robustness check}

In this section, we investigate the robustness of our nested logit specification. We consider the consequences of different a priori nesting of banks (with only two nests) (Table 14), effects of the inflation (Table 15), credit risk and dealer costs (Table 16) as well as the employment of net deposit interest rates (Table 17) ${ }^{28}$. Table reports the market power test for different specifications and finally Table 2 summarize the results of the robustness checks.

The results seem to be fairly robust to forming only two nests (the nest of universal banks including OTP also and nest of specialized banks). Only the interest rate elasticities of higher purchase loans and short-term deposits increased in absolute term, which resulted in a lower PCMs predicted by the Bertrand and the cartel models. The market power test, however, shows similar results to the baseline case. The degree of model fit and the parameters of nest variables for deposit side decreased in the new specification. All parameters are significant and have the expected sign and all the overidentification tests are accepted.

Using real variables (real interest rates, variables at constant prices deflated with the consumer price index) the results are also robust for most of sub-markets. The parameters of explanatory variables are significant and have the expected signs. The only exception is the demand deposit market, where the interest rate parameter is positive, although insignificant. This finding may suggest that the demand for demand deposit is determined by liquidity preferences rather than by real interest rates. The interest rate elasticities and the implied PCMs for higher purchase and personal loans as well as for short-term and long-term deposits are similar to the baseline nested logit model, leaving the results of market power test unchanged. On the overdraft market the degree of competition is rather high in contrast to the baseline case.

Our supply model does not include the riskiness of the banks' loan portfolio. Here we consider riskiness as an exogenous variable and adjust the observed interest rates with the risk premium. We calculate risk premium as the product of nonperforming loans to total loans (as a proxy of non-payment) and the interest rate. Assuming that the whole stock of households' non-performing loans is defaulted, the risk premium computed from the data of specialized banks are 100 to 250 basis points for consumer lending sub-markets. After adjusting the interest rates with the credit risk, the majority of "observed" margins in market of overdraft are under the Bertrand values. For higher purchase and personal loans the results of market power test remain unchanged. In case of higher purchase loans, the "observed" absolute margins have to be reduced further by dealer $\operatorname{costs}^{29}$ of around 300 basis points. Taking into account both credit risk and dealer cost the means of "observed" absolute and relative margins are close to the Bertrand values. However, the majority of "observed" values are still above the Bertrand PCMs.

Since our estimates of risk premiums and dealer cost could be quite imprecise, we also calculated threshold values for the sum of risk premium and dealer cost. At these threshold values, half of the observed margins is under, while the other half is above the Bertrand values. For overdraft this calculated value is relatively low, while for higher purchase and personal loans they are rather high (Table 19).

When we estimate demand for deposit services with net deposit interest rates, the elasticities of overdraft and short-term deposits were lower, which implied higher Bertrand and cartel PCMs than the baseline case. However, "observed" margins were also estimated at a higher level, thus the degree of competition was measured as low for overdraft and short-term deposits and high for long-term deposits similar to the results of baseline nested logit specification. The fit of the model was reasonable good, overidentification tests were also accepted.

Finally we also estimated the nested logit specification with three nests for the whole household deposit market using cost shifters and BLP instruments. The Table 18 shows that the estimated price parameters are positive and significant. Household deposit interest rate has relatively high elasticity particularly when nominal variables are used. Service fee is

\footnotetext{
${ }^{28}$ The net deposit interest rate is defined as the difference between gross deposit interest rate and service fee.

${ }^{29}$ This cost is paid for dealers who sell bank services. The accounting category of operating costs does not include dealer costs.
} 


\section{Table 2}

Robustness test on the results of nested logit specification regarding the degree of competition

\begin{tabular}{|c|c|c|c|c|c|}
\hline & & Two nests & Real variables & $\begin{array}{l}\text { Including credit risk } \\
\text { and dealer cost }\end{array}$ & $\begin{array}{l}\text { Net deposit } \\
\text { interest rate }\end{array}$ \\
\hline \multirow[t]{3}{*}{ Consumer loans } & Overdraft & low & high & high & - \\
\hline & Higher purchase loans & low & low & low & - \\
\hline & Personal loans & low & low & low & - \\
\hline \multirow[t]{3}{*}{ Household deposits } & Demand deposits & low & low & - & low \\
\hline & Short-term deposits & low & low & - & low \\
\hline & Long-term deposits & high & high & - & high \\
\hline
\end{tabular}

Note: Degree of competition is considered low if the majority of observed values are higher than the predicted values of Bertrand model. Degree of competition is considered high if the majority of observed values are lower than the predicted values of Bertrand model.

inelastic or of low elasticity. Regarding the market power test, the estimated observed margins exceed both the predicted Bertrand and cartel values. 


\section{Conclusion}

This paper builds a structural model of the retail banking industry. We estimated residual demand and supply functions of household loans and deposit services. We considered two models of the banking industry: a static, differentiated product Nash-Bertrand oligopoly and a cartel. For each supply model the pricing decisions of the bank depend on the individual bank-level demands. We estimated a discrete choice multinomial logit models of demand for consumers' loan and deposit services. The estimated price elasticities are then used to calculate the price-cost margins implied by the two supply models. We estimated a translog cost function for individual banks to uncover product specific marginal costs. From the estimated cost parameters and the observed interests rates we calculated the "observed" price-cost margins.

We find that the "observed" price-cost margins are very high for overdraft, higher purchase loan, personal loan, and demand deposit and lower for short-term and long-term deposit. The Bertrand model also implies that the margins for consumer loans are large, while for deposit are more modest. We test whether the majority of "observed" margins is under or above the Bertrand value, implying high or low level of competition. Our results suggest that on the overdraft, higher purchase loan, personal loan, demand deposit, and short-term deposit markets the degree of competition is low while the long-term deposit market can be characterized as fairly competitive. However, on the overdraft market if we control for the riskiness of consumer and for inflation, the "observed" margins are closer to competitive values.

Numerous factors, other than collusion, may explain the high margins and banks' competition behavior. The most important are switching costs, habit formation, marketing activity, competition in credit standards and conditions, entry barriers. Barriers to entry into the retail banking market are high in general, i.e. this market segment is less contestable, primarily due to the need for and the high costs associated with the establishment of branch networks. In addition, regulatory barriers to banking competition can also encumber the entry and restrict activity in other areas of financial services. ${ }^{30}$ The public ownership has only a minor relevance for Hungary as a barrier. Higher switching costs including direct costs of switching (such as payments for closing or opening an account) as well as indirect costs (such as the time cost of switching) may also influence competition as a source of pricing power for banks. Finally, low level of price competition can be also caused by the fact that banks spend increasing amounts on sales promotion (competition in costs) and continuously ease the non-price conditions of credit (competition in risks). ${ }^{31}$ As these factors may provide an alternative explanation for high price-cost margins and low level of price competition in the household business line, further research into banks' strategies is required.

\footnotetext{
${ }^{30}$ The EU Competition Commission's retail bank report shows that Hungarian banks face high cross-sectoral restrictions in financial services.

${ }^{31}$ Of the non-price conditions, minimum mandatory contribution and maximum income-proportionate instalment are the most important factors.
} 


\section{References}

Berger, A. (1995): "The Profit-Structure Relationship in Banking - Tests of Market-Power and Efficient-Structure Hypotheses", Journal of Money, Credit, and Banking, 27, pp. 404-31.

Berger, A. and T.H. Hannan (1989): "The Price-Concentration Relationship in Banking", Review of Economics and Statistics, 71, pp. 291-299.

BerRY, S.T. (1994): "Estimating Discrete-Choice Models of Product Differentiation", RAND Journal of Economics, 25, pp. 242-262.

Berri, S., J. Levinsohn and A. Pakes (1995): “Automobile Prices in Market Equilibrium”, Econometrica, 63, pp. 841-890.

BIKKER, J. AND HAAF, K.(2002): "Competition, concentration and their relationship: An empirical analysis of the banking industry", Journal of Banking and Finance 26, pp. 2191-2214.

BresnahAn, T.F. (1982): "The Oligopoly Solution Concept Is Identified", Economics Letters 10, pp. 87-92.

CORTS, K. (1999): "Conduct parameters and the measurement of market power", Journal of Econometrics 88, pp. 227250.

De Bandt, O. And E. P. Davis (2000): "Competition, contestability and market structure in European banking sectors on the eve of EMU", Journal of Banking and Finance 24, pp. 1045-1066.

Degryse, H. And S. Ongena (2005) "Competition and Regulation in the Banking Sector: A Review of the Empirical Evidence on the Sources of the Bank Rents", http://center.uvt.nl/staff/ongena/preprints/do.pdf.

Dick, A. (2002): "Demand Estimation and Consumer Welfare in the Banking Industry", Federal Reserve Board Finance and Economics Discussion Series 58-2002.

EuROPEAN COMmISSION (2006): "Retail Banking Sector Inquiry: Interim Report II: Current Accounts and Related Services, July 17th 2006", http://ec.europa.eu/comm/competition/antitrust/others/sector_inquiries/financial_services/interim_report_2.pdf.

Hannan, T.H. (1997): "Market Share Inequality, the Number of Competitors, and the HHI: An Examination of Bank Pricing", Review of Industrial Organization 12, pp. 23-35.

Hannan, T.H. And A.N. Berger (1991): "The Rigidity of Prices: Evidence from the Banking Industry", American Economic Review 81, pp. 938-945.

Hungarian COMPETITION COMmISsion (2005): "Jelentés a jelzáloghitelezés tárgyában lefolytatott ágazati vizsgálatról", Available at: http://www.gvh.hu/gvh/alpha?do=2\&st=1\&pg=79\&m5 doc $=2366$

IVALDI, M. AND F. VeRBOVEN (2005): "Quantifying the effects from horizontal mergers in European competition policy", International Journal of Industrial Organization 23, pp. 669-691.

KIM, M. (1985): "Scale Economies in Banking: A Methodological Note Journal of Money", Credit and Banking 17, pp. 96-102. KRAFT, E. (2006): "How competitive is the Croatia's Banking System, Croatian National Bank", presented at the EARIE 2006. McFadden, D. (1973): "Conditional Logit Analysis of Qualitative Choice Behavior", Frontiers of Econometrics (ed. by P. Zarembka), New York, Academic Press.

McFadden, D. (1978): "Modeling the Choice of Residential Location", Spatial Interaction Theory and Planning Models (ed. by A. Karlgvist, et al.), Amsterdam, North-Holland.

McFadden, D. (1981): "Econometric Models of Probabilistic Choice", Structural Analysis of Discrete Data. (ed. by C. Manski and D. McFadden), Cambridge, MIT Press.

MórÉ, Cs. And M. NAGy (2004): "Competition in the Hungarian Banking Market", MNB Working Papers, $2004 / 09$.

Nakane, M.I., L.S. Alencar And F. Kanczuk (2006): "Demand for Bank Services and Market Power in Brazilian Banking", Banco Central Do Brasil, Working Paper Series 107.

Neven, D. And L.-H. RölleR (1999): "An Aggregate Structural Model of Competition in the European Banking Industry", International Journal of Industrial Organization 17, pp. 1059-1074.

Nevo, A. (2001): "Measuring Market Power in the Ready-To-Eat Cereal Industry", Econometrica, 69, pp. $307-342$.

PANZAR, J. AND J. Rosse (1987): Testing for "Monopoly" Equilibrium, Journal of Industrial Economics 35, 4: 443-56.

REISS, P. AND F. WOLAK (2005): "Structural Econometric Modeling: Rationales and Examples from Industrial Organization", Handbook of Econometrics, Vol. 6.

Suominen, M. (1994): "Measuring Competition in Banking: A Two-Product Model", Scandinavian Journal of Economics, pp. 95-110.

VÁRHEGYI, É. (2004): Bank Competition in Hungary, Acta Oeconomica, Vol. 54 (4), pp. 403-424. 


\section{Appendix}

\section{Table 3}

Macroeconomic and banking sector-related indicators

\begin{tabular}{|c|c|c|c|c|c|}
\hline & 2001 & 2002 & 2003 & 2004 & 2005 \\
\hline Real GDP growth (per cent) & 3.8 & 3.5 & 3.0 & 4.2 & 4.2 \\
\hline Growth of households' net financial wealth (per cent) & 13.5 & 8.6 & 3.1 & 8.8 & 8.0 \\
\hline Consumer inflation (per cent) & 6.8 & 4.8 & 5.7 & 5.5 & 3.3 \\
\hline Number of banks & 41 & 37 & 36 & 35 & 35 \\
\hline Credit / GDP (per cent) & 26.4 & 26.6 & 32.5 & 35.6 & 39.6 \\
\hline Deposits / GDP (per cent) & 2.9 & 3.3 & 3.1 & 3.2 & 3.4 \\
\hline Bank assets / GDP (per cent) & 71.2 & 71.4 & 78.2 & 75.8 & 80.3 \\
\hline Return on equity (ROE) (per cent) & 19.6 & 19.8 & 23.5 & 29.8 & 30.4 \\
\hline Return on assets (ROA) (per cent) & 1.6 & 1.7 & 1.9 & 2.3 & 2.5 \\
\hline Net interest margin (NIM) (per cent) & 4.1 & 4.2 & 4 & 4 & 3.9 \\
\hline
\end{tabular}

This table reports basic macroeconomic and financial indicators. Credit and deposit aggregates include corporate and household sectors. Observations are from year-end.

Source: $M N B$

\section{Table 4}

Concentration of household credit sub-markets at the end of 2004

\begin{tabular}{lc}
\hline 2005 & Herfindhal index \\
\hline Overdraft & 1884 \\
Higher purchase loans & 3517 \\
Personal loans & 1959 \\
Car purchase loans & 1056 \\
Mortgage loans with general purpose & 1458 \\
Housing loans & 2736 \\
\hline Demand deposits & 3012 \\
Short-term deposits & 2090 \\
Long-term deposits & 2282 \\
\hline
\end{tabular}

This table reports Herfindhal indices. We take into account commercial banks consolidated with their subsidiaries. Source: MNB. 


\section{Table 5}

\section{Descriptive statistics}

\begin{tabular}{ll|c|c|c|c|c}
\hline & & Min. & Max. & Mean & Median & St. dev. \\
\hline Interest rates & Overdraft (per cent) & 10.52 & 39.43 & 19.71 & 19.67 & 5.09 \\
& Higher purchase loans (per cent) & 24.82 & 45.76 & 34.76 & 35.55 & 5.01 \\
& Personal loans (per cent) & 18.28 & 55.76 & 28.80 & 27.90 & 5.79 \\
& Demand deposit (per cent) & 0.02 & 9.81 & 3.20 & 2.85 & 2.06 \\
& Short-term deposit (per cent) & 3.55 & 12.10 & 8.10 & 7.93 & 2.04 \\
& Long-term deposit (per cent) & 2.50 & 13.03 & 7.56 & 7.39 & 2.16 \\
\hline Other variables & Service fees/Total deposits (per cent) & 0.06 & 15.65 & 0.59 & 0.49 & 0.88 \\
& Number of branch & 1 & 432 & 83.81 & 31 & 115.68 \\
& Employees per branch & 10.37 & 125.50 & 40.82 & 29.55 & 28.06 \\
& Banks' age & 3 & 82 & 23.76 & 16 & 21.40 \\
\hline Instrumental variables & Non-performing loans / Total loans (per cent) & 0.01 & 22.37 & 2.31 & 1.48 & 3.14 \\
& Capital adequacy ratio (per cent) & 5.50 & 61.2 & 12.36 & 11.20 & 11.31 \\
& Liquid assets / Total assets (per cent) & 8.86 & 53.68 & 25.17 & 24.22 & 9.65 \\
Operational cost / Total deposits (per cent) & 0.5 & 43 & 4.11 & 1.23 & 9.2 \\
& Total loans / Total assets (per cent) & 31.31 & 81.59 & 62.41 & 66.01 & 11.95 \\
Personal expenses / Number of employees & & & & \\
(HUF, Thousands) & 110.60 & 2110 & 410.18 & 370.13 & 170.35 \\
\hline
\end{tabular}

This table reports summary statistics of the variables. 


\section{Table 6}

Results of demand estimations using logit specification and IV estimation with cost shifters and BLP instruments

\begin{tabular}{|c|c|c|c|c|c|c|}
\hline & \multicolumn{3}{|c|}{ Consumer loans } & \multicolumn{3}{|c|}{ Household deposits } \\
\hline & Overdraft & $\begin{array}{c}\text { Higher } \\
\text { purchase loans }\end{array}$ & $\begin{array}{l}\text { Personal } \\
\text { loans }\end{array}$ & $\begin{array}{l}\text { Demand } \\
\text { deposits }\end{array}$ & $\begin{array}{l}\text { Short-term } \\
\text { deposits }\end{array}$ & $\begin{array}{c}\text { Long-term } \\
\text { deposits }\end{array}$ \\
\hline Interest rate & $\begin{array}{l}-0.30^{\star *} \\
(-1.99)\end{array}$ & $\begin{array}{l}-0.14^{* *} \\
(-2.03)\end{array}$ & $\begin{array}{l}-0.22^{\star *} \\
(-2.41)\end{array}$ & $\begin{array}{l}1.58^{\star \star \star} \\
(10.73)\end{array}$ & $\begin{array}{l}1.13^{* \star *} \\
(7.61)\end{array}$ & $\begin{array}{l}0.84^{* * *} \\
(3.32)\end{array}$ \\
\hline Service fee & - & - & - & $\begin{array}{l}-0.02^{*} \\
(-1.84)\end{array}$ & $\begin{array}{l}-0.01^{\star * *} \\
(-18.21)\end{array}$ & $\begin{array}{l}-3.82^{* \star *} \\
(-4.32)\end{array}$ \\
\hline Number of branch & $\begin{array}{l}0.03^{\star \star \star} \\
(5.16)\end{array}$ & $\begin{array}{l}0.06^{\star \star \star} \\
(3.52)\end{array}$ & $\begin{array}{l}0.01^{\star *} \\
(2.45)\end{array}$ & $\begin{array}{l}0.06^{\star \star \star} \\
(15.72)\end{array}$ & $\begin{array}{c}0.04^{\star * \star} \\
(19.02)\end{array}$ & $\begin{array}{l}0.04^{\star \star \star} \\
(6.70)\end{array}$ \\
\hline Employees per branch & $\begin{array}{r}0.02^{*} \\
(1.86)\end{array}$ & $\begin{array}{l}0.01^{\star * \star} \\
(5.06)\end{array}$ & $\begin{array}{l}-0.05^{*} \\
(-1.89)\end{array}$ & $\begin{array}{l}-0.01^{\star * *} \\
(-5.45)\end{array}$ & $\begin{array}{l}0.002^{*} \\
(1.71)\end{array}$ & $\begin{array}{l}0.32^{* * *} \\
(10.18)\end{array}$ \\
\hline Banks' age & $\begin{array}{l}-0.01 \\
(-1.19)\end{array}$ & $\begin{array}{l}0.98^{\star * *} \\
(7.49)\end{array}$ & $\begin{array}{l}0.02^{\star \star \star} \\
(1.67)\end{array}$ & $\begin{array}{l}0.03^{* *} \\
(2.34)\end{array}$ & $\begin{array}{l}0.07^{\star \star \star} \\
(11.69)\end{array}$ & $\begin{array}{l}-0.22^{\star \star \star} \\
(-13.38)\end{array}$ \\
\hline Big (dummy) & $\begin{array}{l}-8.88^{* \star \star} \\
(-3.55)\end{array}$ & $\begin{array}{l}-61.69^{* * *} \\
(-12.24)\end{array}$ & $\begin{array}{l}-3.45^{*} \\
(-1.77)\end{array}$ & $\begin{array}{l}-19.25^{\star \star \star} \\
(-11.29)\end{array}$ & $\begin{array}{l}-10.85^{\star \star *} \\
(-12.55)\end{array}$ & $\begin{array}{l}5.13^{\text {** }} \\
(2.58)\end{array}$ \\
\hline Medium (dummy) & $\begin{array}{l}-1.42^{\star \star} \\
(2.42)\end{array}$ & $\begin{array}{l}-3.90^{\star \star \star} \\
(-2.58)\end{array}$ & 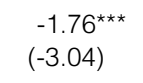 & $\begin{array}{l}-3.89^{\star \star \star} \\
(-7.29)\end{array}$ & $\begin{array}{l}-0.61^{\star \star *} \\
(-2.79)\end{array}$ & $\begin{array}{c}0.08 \\
(0.32)\end{array}$ \\
\hline Interest rate elasticity & -5.44 & -4.65 & -5.91 & 5.02 & 8.85 & 6.23 \\
\hline Service fee elasticity & - & - & - & -0.03 & -0.16 & -1.70 \\
\hline
\end{tabular}

\begin{tabular}{|c|c|c|c|c|c|c|}
\hline \multirow{2}{*}{$\begin{array}{l}\text { Instruments } \\
\text { First stage partial } R^{2} \text { / interest rate }\end{array}$} & \multicolumn{6}{|c|}{ Cost+BLP } \\
\hline & 0.59 & 0.42 & 0.52 & 0.68 & 0.65 & 0.48 \\
\hline First stage partial $R^{2}$ / service fee & - & - & - & 0.91 & 0.94 & 0.35 \\
\hline First stage $F$ test / interest rate & 40.48 & 14.57 & 16.35 & 25.00 & 30.90 & 12.26 \\
\hline First stage F test / service fee & - & - & - & 13000.06 & 2336.42 & 24.93 \\
\hline Overidentification (P-value) & 0.14 & 0.04 & 0.10 & 0.12 & 0.15 & 0.17 \\
\hline Observations & 438 & 78 & 190 & 483 & 577 & 386 \\
\hline Period under review & 2003-2005 & $2004-2005$ & $2004-2005$ & 2003-2005 & $2003-2005$ & 2003-2005 \\
\hline
\end{tabular}

This table reports the 2SLS estimates of bank level loan and deposit services demand functions using logit specification. The dependent variables are the logarithms of market shares of each banks minus the outside good on different submarkets. The explanatory variables are the interests rates, service fee (on the consumer loan markets the annual charge (APRC) that includes all service fees), bank characteristics (such as number of existing branches, employees per branches, age of the banks, dummies for the biggest bank and for the universal banks) and time dummies. $t$-statistics are reported in parenthesis. Above we report the computed average interest rate and service fee elasticities and the characteristics of the estimations. 


\section{Table 7}

Results of demand estimations using nested logit specification and IV estimation with cost shifters and BLP instruments

\begin{tabular}{|c|c|c|c|c|c|c|}
\hline & \multicolumn{3}{|c|}{ Consumer loans } & \multicolumn{3}{|c|}{ Household deposits } \\
\hline & Overdraft & $\begin{array}{c}\text { Higher } \\
\text { purchase loans }\end{array}$ & $\begin{array}{l}\text { Personal } \\
\text { loans }\end{array}$ & $\begin{array}{l}\text { Demand } \\
\text { deposits }\end{array}$ & $\begin{array}{l}\text { Short-term } \\
\text { deposits }\end{array}$ & $\begin{array}{c}\text { Long-term } \\
\text { deposits }\end{array}$ \\
\hline Interest rate & $\begin{array}{l}-0.13^{\star \star \star} \\
(-7.22)\end{array}$ & $\begin{array}{l}-0.07^{\star \star \star} \\
(-9.41)\end{array}$ & $\begin{array}{l}-0.09^{\star *} \\
(-2.14)\end{array}$ & $\begin{array}{l}1.16^{* \star *} \\
(6.45)\end{array}$ & $\begin{array}{c}1.72^{\star \star \star} \\
(10.26)\end{array}$ & $\begin{array}{l}0.29^{* *} \\
(2.18)\end{array}$ \\
\hline Service fee & - & - & - & $\begin{array}{l}-0.49^{\star \star \star} \\
(-11.00)\end{array}$ & $\begin{array}{l}-0.73^{\star * *} \\
(-8.53)\end{array}$ & $\begin{array}{l}-3.75^{\star *} \\
(-2.39)\end{array}$ \\
\hline Nest variable $(\bar{S})$ & $\begin{array}{l}0.85^{\star \star \star} \\
(17.85)\end{array}$ & $\begin{array}{c}0.27 \\
(0.25)\end{array}$ & $\begin{array}{l}0.84^{\star \star \star} \\
(14.51)\end{array}$ & $\begin{array}{l}0.64^{* \star \star} \\
(2.72)\end{array}$ & $\begin{array}{l}0.37^{* \star *} \\
(2.69)\end{array}$ & $\begin{array}{l}0.78^{* \star \star} \\
(6.54)\end{array}$ \\
\hline Number of branch & $\begin{array}{l}0.006^{\star * *} \\
(5.62)\end{array}$ & $\begin{array}{l}0.001^{\star * *} \\
(4.03)\end{array}$ & $\begin{array}{l}0.003^{\star \star \star} \\
(5.52)\end{array}$ & $\begin{array}{l}0.01^{\star \star \star} \\
(5.79)\end{array}$ & $\begin{array}{l}0.02^{\star \star \star} \\
(9.79)\end{array}$ & $\begin{array}{l}0.01^{\star * \star} \\
(8.19)\end{array}$ \\
\hline Employees per branch & $\begin{array}{l}0.007^{\star \star \star} \\
(6.99)\end{array}$ & $\begin{array}{c}0.002 \\
(0.08)\end{array}$ & $\begin{array}{r}0.01^{*} \\
(1.93)\end{array}$ & $\begin{array}{l}0.04^{\star \star *} \\
(4.15)\end{array}$ & $\begin{array}{l}0.06^{\star \star \star} \\
(9.18)\end{array}$ & $\begin{array}{c}0.003 \\
(0.89)\end{array}$ \\
\hline
\end{tabular}

\begin{tabular}{l|c|c|c|c|c|c}
\hline Interest rate elasticity & -2.34 & -2.12 & -2.59 & 10.77 & 19.87 & 8.24 \\
\hline Service fee elasticity & - & - & - & -0.06 & -0.41 & -4.85 \\
\hline
\end{tabular}

\begin{tabular}{l|c|c|c|c|c|c}
\hline Nests & \multicolumn{5}{|c}{ Nest1: OTP; Nest2: Universal banks; Nest3: Specialized banks } \\
\hline Instruments & \multicolumn{5}{|c|}{ Cost+BLP } \\
\hline First stage partial R ${ }^{2}$ interest rate & 0.40 & 0.46 & 0.52 & 0.38 & 0.69 & 0.53 \\
\hline First stage partial R / service fee & - & - & - & 0.95 & 0.30 & 0.31 \\
\hline First stage partial R / nest variable & 0.88 & 0.81 & 0.43 & 0.47 & 0.41 & 0.39 \\
\hline First stage F test / interest rate & 25.91 & 31.01 & 31.10 & 20.77 & 32.83 & 15.61 \\
\hline First stage F test / service fee & - & - & - & 495.37 & 19.93 & 11.01 \\
\hline First stage F test / nest variable & 45.50 & 38.89 & 18.60 & 10.76 & 21.10 & 13.86 \\
\hline Overidentification (P-value) & 0.54 & 0.13 & 0.44 & 0.10 & 0.23 & 0.45 \\
\hline Observations & 438 & 78 & 190 & 483 & 577 & 386 \\
\hline Period under review & $2003-2005$ & $2004-2005$ & $2004-2005$ & $2003-2005$ & $2003-2005$ & $2003-2005$ \\
\hline
\end{tabular}

This table reports the 2SLS estimates of bank level loan and deposit services demand functions using nested logit specification with 3 nests. The dependent variables are the logarithms of market shares of each banks minus the outside good on different submarkets. The explanatory variables are the interests rates, service fees (on the consumer loan markets the annual charge (APRC) that includes all service fees), nest variables, bank characteristics (such as number of existing branches, employes per branches) and time dummies. $t$-statistics are reported in parenthesis. See the text for description of variables and instrument sets. Above we report the computed average interest rate and service fee elasticities and the characteristics of the estimations. 


\section{Table 8}

Results for cost functions

\begin{tabular}{|c|c|c|c|c|c|c|}
\hline & \multicolumn{3}{|c|}{ Consumer loans } & \multicolumn{3}{|c|}{ Household deposits } \\
\hline & Overdraft & $\begin{array}{c}\text { Higher } \\
\text { purchase loans }\end{array}$ & $\begin{array}{l}\text { Personal } \\
\text { loans }\end{array}$ & $\begin{array}{l}\text { Demand } \\
\text { deposits }\end{array}$ & $\begin{array}{l}\text { Short-term } \\
\text { deposits }\end{array}$ & $\begin{array}{l}\text { Long-term } \\
\text { deposits }\end{array}$ \\
\hline InQ1 (output in a sub-market) & $\begin{array}{l}0.21^{\star \star *} \\
(9.57)\end{array}$ & $\begin{array}{l}0.25^{\star \star \star} \\
(10.13)\end{array}$ & $\begin{array}{c}0.23^{\star \star \star} \\
(10.57)\end{array}$ & $\begin{array}{l}0.09^{\star \star \star} \\
(2.24)\end{array}$ & $\begin{array}{l}0.15^{\star \star \star} \\
(12.71)\end{array}$ & $\begin{array}{l}0.05^{\star \star *} \\
(9.03)\end{array}$ \\
\hline InQ2 (rest of total assets) & $\begin{array}{c}0.61^{\star \star \star} \\
(15.16)\end{array}$ & $\begin{array}{l}0.51^{\star \star \star} \\
(6.06)\end{array}$ & $\begin{array}{l}0.27^{\star \star \star} \\
(22.77)\end{array}$ & $\begin{array}{c}0.89^{\star \star \star} \\
(12.51)\end{array}$ & $\begin{array}{l}0.74^{\star \star \star} \\
(30.32)\end{array}$ & $\begin{array}{c}0.93^{\star \star \star} \\
(114.29)\end{array}$ \\
\hline LnQ1InQ1 & $\begin{array}{l}0.01^{\star \star \star} \\
(9.39)\end{array}$ & $\begin{array}{l}0.001^{\star \star \star} \\
(7.21)\end{array}$ & $\begin{array}{l}0.003^{\star \star *} \\
(15.02)\end{array}$ & $\begin{array}{l}0.003^{\star * \star} \\
(3.68)\end{array}$ & $\begin{array}{l}0.02^{\star \star \star} \\
(30.60)\end{array}$ & $\begin{array}{l}0.001^{\star \star \star} \\
(6.48)\end{array}$ \\
\hline LnQ1InQ2 & $\begin{array}{l}-0.02^{* * *} \\
(-7.86)\end{array}$ & $\begin{array}{l}-0.12^{* * *} \\
(-8.27)\end{array}$ & $\begin{array}{l}-0.02^{\star \star \star} \\
(-9.87)\end{array}$ & $\begin{array}{r}0.001 \\
(1.38)\end{array}$ & $\begin{array}{l}-0.02^{* * *} \\
(-11.33)\end{array}$ & $\begin{array}{l}-0.001^{* * *} \\
(-5.34)\end{array}$ \\
\hline LnQ2InQ2 & $\begin{array}{l}0.02^{\star \star *} \\
(7.61)\end{array}$ & $\begin{array}{l}0.02^{\star \star \star} \\
(6.05)\end{array}$ & $\begin{array}{l}0.03^{\star \star \star} \\
(6.93)\end{array}$ & $\begin{array}{l}-0.005 \\
(-1.06)\end{array}$ & $\begin{array}{l}0.01^{* * *} \\
(8.36)\end{array}$ & $\begin{array}{l}0.002^{* * *} \\
(4.92)\end{array}$ \\
\hline LnP1 (price of labor) & $\begin{array}{l}0.54^{\star \star \star} \\
(23.84)\end{array}$ & $\begin{array}{c}0.37^{\star \star \star} \\
(11.69)\end{array}$ & $\begin{array}{c}0.47^{\star \star \star} \\
(16.87)\end{array}$ & $\begin{array}{l}0.31^{\star \star \star} \\
(11.90)\end{array}$ & $\begin{array}{l}0.45^{\star \star \star} \\
(22.69)\end{array}$ & $\begin{array}{l}0.41^{\star \star \star} \\
(21.39)\end{array}$ \\
\hline LnP2 (price of capital) & $\begin{array}{c}0.44^{\star \star \star} \\
(19.26)\end{array}$ & $\begin{array}{l}0.60^{\star \star \star} \\
(18.78)\end{array}$ & $\begin{array}{l}0.51^{\star \star \star} \\
(17.03)\end{array}$ & $\begin{array}{l}0.51^{\star * \star} \\
(26.08)\end{array}$ & $\begin{array}{l}0.68^{\star \star \star} \\
(23.73)\end{array}$ & $\begin{array}{l}0.51^{\star * *} \\
(25.98)\end{array}$ \\
\hline LnP1 $\ln P 1$ & $\begin{array}{c}0.03^{\star \star \star} \\
(23.35)\end{array}$ & $\begin{array}{l}0.01^{\star \star \star} \\
(4.28)\end{array}$ & $\begin{array}{l}0.02^{\star \star \star} \\
(10.75)\end{array}$ & $\begin{array}{l}-0.01^{\star * *} \\
(5.91)\end{array}$ & $\begin{array}{l}-0.01^{\star \star \star} \\
(-6.54)\end{array}$ & $\begin{array}{c}0.03^{\star \star *} \\
(23.13)\end{array}$ \\
\hline LnP2InP2 & $\begin{array}{l}0.02^{\star \star \star} \\
(13.62)\end{array}$ & $\begin{array}{l}0.01^{\star \star \star} \\
(8.25)\end{array}$ & $\begin{array}{l}-0.008^{\text {** }} \\
(-6.57)\end{array}$ & $\begin{array}{l}-0.01^{\star \star \star} \\
(-7.18)\end{array}$ & $\begin{array}{l}-0.01^{\star \star *} \\
(-23.73)\end{array}$ & $\begin{array}{c}-0.01^{\star \star \star} \\
(-12.62)\end{array}$ \\
\hline LnP1LnP2 & $\begin{array}{l}-0.03^{\star \star *} \\
(-18.35)\end{array}$ & $\begin{array}{l}-0.01^{* * *} \\
(-7.12)\end{array}$ & $\begin{array}{l}-0.005^{\star \star \star} \\
(-9.63)\end{array}$ & $\begin{array}{l}0.01^{* * *} \\
(6.38)\end{array}$ & $\begin{array}{l}0.01^{* * *} \\
(9.31)\end{array}$ & $\begin{array}{l}-0.001^{\star * \star} \\
(-3.40)\end{array}$ \\
\hline LnQ1LnP1 & $\begin{array}{l}0.01^{* * *} \\
(11.65)\end{array}$ & $\begin{array}{l}-0.01^{\star * *} \\
(-9.76)\end{array}$ & $\begin{array}{l}0.004^{* * *} \\
(4.65)\end{array}$ & $\begin{array}{l}-0.01^{\star \star *} \\
(-7.53)\end{array}$ & $\begin{array}{l}-0.01^{* * *} \\
(-7.31)\end{array}$ & $\begin{array}{l}0.001^{* * *} \\
(6.21)\end{array}$ \\
\hline LnQ1LnP2 & $\begin{array}{l}-0.01^{\star * *} \\
(-10.01)\end{array}$ & $\begin{array}{l}0.01^{\star * *} \\
(3.69)\end{array}$ & $\begin{array}{l}-0.001^{* * *} \\
(-4.75)\end{array}$ & $\begin{array}{l}-0.01^{\star * *} \\
(7.74)\end{array}$ & $\begin{array}{l}0.01^{\star * *} \\
(7.09)\end{array}$ & $\begin{array}{l}0.001^{* * *} \\
(3.86)\end{array}$ \\
\hline LnQ2LnP1 & $\begin{array}{c}-0.04^{\star \star \star} \\
(-15.92)\end{array}$ & $\begin{array}{l}-0.01^{\star \star *} \\
(-6.15)\end{array}$ & $\begin{array}{l}-0.02^{\star \star \star} \\
(-6.25)\end{array}$ & $\begin{array}{l}0.08^{\star \star \star} \\
(3.56)\end{array}$ & $\begin{array}{l}0.001^{\text {** }} \\
(6.86)\end{array}$ & $\begin{array}{l}-0.01^{\star \star \star} \\
(-6.78)\end{array}$ \\
\hline LnQ2LnP2 & $\begin{array}{c}0.03^{\text {***}} \\
(14.20)\end{array}$ & $\begin{array}{l}0.01^{\star * *} \\
(6.28)\end{array}$ & $\begin{array}{l}0.01^{\star \star \star} \\
(3.15)\end{array}$ & $\begin{array}{l}-0.01^{\star * \star} \\
(-3.24)\end{array}$ & $\begin{array}{l}-0.002^{\star \star \star} \\
(-12.93)\end{array}$ & $\begin{array}{l}0.004^{\star \star \star} \\
(4.81)\end{array}$ \\
\hline Adjusted $R^{2}$ & 0.99 & 0.99 & 0.99 & 0.99 & 0.99 & 0.99 \\
\hline
\end{tabular}

This table reports the $3 S L S$ estimates of a system of a translog cost function and cost share equations. The dependent variable are the logarithms of total cost of each banks. The explanatory variables include the outputs and input prices. $t$-statistics are reported in parenthesis. See the text for description of variables and instrument sets. 


\section{Table 9}

Average marginal costs for household sub-markets

\begin{tabular}{|c|c|c|c|c|c|c|}
\hline \multirow[b]{2}{*}{ Per cent } & \multicolumn{3}{|c|}{ Consumer loans } & \multicolumn{3}{|c|}{ Household deposits } \\
\hline & Overdraft & $\begin{array}{c}\text { Higher } \\
\text { purchase loans }\end{array}$ & $\begin{array}{l}\text { Personal } \\
\text { loans }\end{array}$ & $\begin{array}{l}\text { Demand } \\
\text { deposits }\end{array}$ & $\begin{array}{l}\text { Short-term } \\
\text { deposits }\end{array}$ & $\begin{array}{l}\text { Long-term } \\
\text { deposits }\end{array}$ \\
\hline Observed (estimated $\mathrm{c}_{\mathrm{jt}}$ ) & 0.53 & 6.79 & 1.43 & 1.69 & 0.07 & 0.52 \\
\hline \multicolumn{7}{|c|}{ Logit specification } \\
\hline Bertrand & 6.87 & 17.03 & 14.50 & 5.38 & 0.20 & 0.61 \\
\hline Cartel & 0.89 & 6.81 & 6.98 & 5.20 & 0.02 & 0.06 \\
\hline \multicolumn{7}{|c|}{ Nested logit specification } \\
\hline Bertrand & 0.91 & 9.07 & 8.70 & 5.22 & 0.98 & 0.51 \\
\hline Cartel & 0.09 & 0.23 & 0.46 & 4.77 & 0.58 & 0.02 \\
\hline
\end{tabular}

This table reports the means of the marginal costs from the cost function estimations and residual marginal costs computed from the Bertrand and cartel models first-order conditions with the estimated demand elascticities.

\section{Table 10}

Average interest rates and absolute price-cost margins for household sub-markets

\begin{tabular}{|c|c|c|c|c|c|c|}
\hline & \multicolumn{3}{|c|}{ Consumer loans } & \multicolumn{3}{|c|}{ Household deposits } \\
\hline & Overdraft & $\begin{array}{c}\text { Higher } \\
\text { purchase loans }\end{array}$ & $\begin{array}{l}\text { Personal } \\
\text { loans }\end{array}$ & $\begin{array}{l}\text { Demand } \\
\text { deposits }\end{array}$ & $\begin{array}{l}\text { Short-term } \\
\text { deposits }\end{array}$ & $\begin{array}{l}\text { Long-term } \\
\text { deposits }\end{array}$ \\
\hline Average interest rate (per cent) & $\begin{array}{c}19.71 \\
(15.74-29.56)\end{array}$ & $\begin{array}{c}34.95 \\
(26.39-42.11)\end{array}$ & $\begin{array}{c}28.80 \\
(21.67-35.17)\end{array}$ & $\begin{array}{c}3.20 \\
(1.00-6.99)\end{array}$ & $\begin{array}{c}8.11 \\
(4.99-11.19)\end{array}$ & $\begin{array}{c}7.62 \\
(4.46-11.59)\end{array}$ \\
\hline \multicolumn{7}{|c|}{ Means of absolute PCMs (per cent) } \\
\hline Observed $\left(c_{\mathrm{jt}}=0\right)$ & $\begin{array}{c}7.73 \\
(3.86-21.86)\end{array}$ & $\begin{array}{c}26.14 \\
(15.05-37.22)\end{array}$ & $\begin{array}{c}19.71 \\
(11.83-31.89)\end{array}$ & $\begin{array}{c}4.83 \\
(1.03-6.15)\end{array}$ & $\begin{array}{c}1.08 \\
(0.01-4.33)\end{array}$ & $\begin{array}{c}1.82 \\
(0.01-4.90)\end{array}$ \\
\hline Observed (with estimated $c_{j t}$ ) & $\begin{array}{c}7.19 \\
(1.55-11.34)\end{array}$ & $\begin{array}{c}19.35 \\
(8.72-29.89)\end{array}$ & $\begin{array}{c}18.27 \\
(13.71-21.81)\end{array}$ & $\begin{array}{c}3.14 \\
(0.12-4.13)\end{array}$ & $\begin{array}{c}1.01 \\
(0.01-3.93)\end{array}$ & $\begin{array}{c}1.31 \\
(0.02-4.27)\end{array}$ \\
\hline \multicolumn{7}{|c|}{ Logit specification } \\
\hline Bertrand & $\begin{array}{c}3.60 \\
(3.37-4.73)\end{array}$ & $\begin{array}{c}7.48 \\
(7.33-7.78)\end{array}$ & $\begin{array}{c}4.93 \\
(4.59-7.39)\end{array}$ & $\begin{array}{c}0.64 \\
(0.62-0.81)\end{array}$ & $\begin{array}{c}0.92 \\
(0.88-1.15)\end{array}$ & $\begin{array}{c}1.23 \\
(1.18-1.74)\end{array}$ \\
\hline Cartel & $\begin{array}{c}9.04 \\
(3.55-21.05)\end{array}$ & $\begin{array}{c}21.45 \\
(18.99-26.22)\end{array}$ & $\begin{array}{c}12.29 \\
(9.15-17.20)\end{array}$ & $\begin{array}{c}1.04 \\
(0.71-1.56)\end{array}$ & $\begin{array}{c}2.14 \\
(1.96-2.29)\end{array}$ & $\begin{array}{c}1.79 \\
(1.37-2.57)\end{array}$ \\
\hline \multicolumn{7}{|c|}{ Nested logit specification } \\
\hline Bertrand & $\begin{array}{c}7.61 \\
(7.50-8.12)\end{array}$ & $\begin{array}{c}13.39 \\
(7.56-23.99)\end{array}$ & $\begin{array}{c}11.51 \\
(10.92-14.28)\end{array}$ & $\begin{array}{c}0.40 \\
(0.31-0.95)\end{array}$ & $\begin{array}{c}0.41 \\
(0.36-0.74)\end{array}$ & $\begin{array}{c}1.30 \\
(0.76-4.81)\end{array}$ \\
\hline Cartel & $\begin{array}{c}9.38 \\
(8.61-9.92)\end{array}$ & $\begin{array}{c}22.63 \\
(15.56-31.99)\end{array}$ & $\begin{array}{c}22.94 \\
(19.11-29.82)\end{array}$ & $\begin{array}{c}0.82 \\
(0.30-1.80)\end{array}$ & $\begin{array}{c}0.58 \\
(0.11-1.12)\end{array}$ & $\begin{array}{c}2.37 \\
(0.40-7.88)\end{array}$ \\
\hline
\end{tabular}

This table reports the means of interest rates as well as the "observed" and implied absolute price-cost margins. The "observed" PCMs are calculated with the observed interest rates and estimated marginal cost. The implied PCMs are calculated with the estimated demand elascticities. The intervals in parenthesis correspond to the range between values of $10 \%$ and $90 \%$ percentiles of the distribution. Absolute price-cost margins are defined as $r^{l}-r-c^{l}$ and $r-r^{d}-c^{d}$. 


\section{Table 11}

Average interest rates and relative price-cost margins for household sub-markets

\begin{tabular}{|c|c|c|c|c|c|c|}
\hline & \multicolumn{3}{|c|}{ Consumer loans } & \multicolumn{3}{|c|}{ Household deposits } \\
\hline & Overdraft & $\begin{array}{c}\text { Higher } \\
\text { purchase loans }\end{array}$ & $\begin{array}{l}\text { Personal } \\
\text { loans }\end{array}$ & $\begin{array}{l}\text { Demand } \\
\text { deposits }\end{array}$ & $\begin{array}{l}\text { Short-term } \\
\text { deposits }\end{array}$ & $\begin{array}{l}\text { Long-term } \\
\text { deposits }\end{array}$ \\
\hline Average interest rates (per cent) & $\begin{array}{c}19.71 \\
(15.74-29.56)\end{array}$ & $\begin{array}{c}34.95 \\
(26.39-42.11)\end{array}$ & $\begin{array}{c}28.80 \\
(21.67-35.17)\end{array}$ & $\begin{array}{c}3.20 \\
(1.00-6.99)\end{array}$ & $\begin{array}{c}8.11 \\
(4.99-11.19)\end{array}$ & $\begin{array}{c}7.62 \\
(4.46-11.59)\end{array}$ \\
\hline \multicolumn{7}{|c|}{ Means of relative PCMs (per cent) } \\
\hline Observed $\left(c_{j t}=0\right)$ & $\begin{array}{c}0.51 \\
(0.28-0.76)\end{array}$ & $\begin{array}{c}0.92 \\
(0.56-1.33)\end{array}$ & $\begin{array}{c}0.74 \\
(0.62-0.84)\end{array}$ & $\begin{array}{c}1.28 \\
(0.48-1.56)\end{array}$ & $\begin{array}{c}0.14 \\
(0.01-0.53)\end{array}$ & $\begin{array}{c}0.22 \\
(0.01-0.73)\end{array}$ \\
\hline Observed (with estimated $\mathrm{c}_{\mathrm{jt}}$ ) & $\begin{array}{c}0.41 \\
(0.12-0.61)\end{array}$ & $\begin{array}{c}0.61 \\
(0.25-0.81)\end{array}$ & $\begin{array}{c}0.65 \\
(0.48-0.75)\end{array}$ & $\begin{array}{c}0.85 \\
(0.12-1.12)\end{array}$ & $\begin{array}{c}0.13 \\
(0.02-0.31)\end{array}$ & $\begin{array}{c}0.17 \\
(0.07-0.44)\end{array}$ \\
\hline \multicolumn{7}{|c|}{ Logit specification } \\
\hline Bertrand & $\begin{array}{c}0.20 \\
(0.13-0.28)\end{array}$ & $\begin{array}{c}0.22 \\
(0.17-0.29)\end{array}$ & $\begin{array}{c}0.18 \\
(0.11-0.24)\end{array}$ & $\begin{array}{c}0.39 \\
(0.10-0.63)\end{array}$ & $\begin{array}{c}0.12 \\
(0.10-0.18)\end{array}$ & $\begin{array}{c}0.16 \\
(0.10-0.32)\end{array}$ \\
\hline Cartel & $\begin{array}{c}0.50 \\
(0.31-0.72)\end{array}$ & $\begin{array}{c}0.64 \\
(0.32-1.55)\end{array}$ & $\begin{array}{c}0.45 \\
(0.30-0.64)\end{array}$ & $\begin{array}{c}0.51 \\
(0.13-1.31)\end{array}$ & $\begin{array}{c}0.28 \\
(0.19-0.40)\end{array}$ & $\begin{array}{c}0.26 \\
(0.15-0.42)\end{array}$ \\
\hline \multicolumn{7}{|c|}{ Nested logit specification } \\
\hline Bertrand & $\begin{array}{c}0.51 \\
(0.21-1.16)\end{array}$ & $\begin{array}{c}0.47 \\
(0.18-1.21)\end{array}$ & $\begin{array}{c}0.45 \\
(0.26-0.55)\end{array}$ & $\begin{array}{c}0.15 \\
(0.04-0.36)\end{array}$ & $\begin{array}{c}0.06 \\
(0.03-0.11)\end{array}$ & $\begin{array}{c}0.18 \\
(0.07-0.88)\end{array}$ \\
\hline Cartel & $\begin{array}{c}0.62 \\
(0.28-1.37)\end{array}$ & $\begin{array}{c}0.70 \\
(0.35-1.41)\end{array}$ & $\begin{array}{c}0.82 \\
(0.49-1.13)\end{array}$ & $\begin{array}{c}0.30 \\
(0.05-0.74)\end{array}$ & $\begin{array}{c}0.10 \\
(0.01-0.26)\end{array}$ & $\begin{array}{c}0.34 \\
(0.05-1.23)\end{array}$ \\
\hline
\end{tabular}

This table reports the means of interest rates as well as the "observed" and implied relative price-cost margins. The "observed" PCMs are calculated with the observed interest rates and estimated marginal cost. The implied PCMs are calculated with the estimated demand elascticities. The intervals in parenthesis correspond to the range between values of $10 \%$ and $90 \%$ percentiles of the distribution. Relative price-cost margins equal to the ratio of absolute price-cost margins to interest rates $\left(r^{l}\right.$ and $\left.r^{d}\right)$. 


\section{Table 12}

Change of relative price-cost margins in time

\begin{tabular}{|c|c|c|c|c|c|c|}
\hline \multirow[t]{2}{*}{ Means of relative PCMs } & \multicolumn{3}{|c|}{ Consumer loans } & \multicolumn{3}{|c|}{ Household deposits } \\
\hline & Overdraft & $\begin{array}{c}\text { Higher } \\
\text { purchase loans }\end{array}$ & $\begin{array}{l}\text { Personal } \\
\text { loans }\end{array}$ & $\begin{array}{l}\text { Demand } \\
\text { deposits }\end{array}$ & $\begin{array}{l}\text { Short-term } \\
\text { deposits }\end{array}$ & $\begin{array}{c}\text { Long-term } \\
\text { deposits }\end{array}$ \\
\hline \multicolumn{7}{|c|}{ Observed (with estimated $c_{j t}$ ) } \\
\hline 2003 & 0.46 & - & - & 0.89 & 0.18 & 0.14 \\
\hline 2004 & 0.41 & 0.58 & 0.71 & 1.03 & 0.11 & 0.22 \\
\hline 2005 & 0.35 & 0.67 & 0.58 & 0.63 & 0.06 & 0.09 \\
\hline \multicolumn{7}{|c|}{ Logit specification } \\
\hline \multicolumn{7}{|l|}{ Bertrand } \\
\hline 2003 & 0.22 & - & - & 0.34 & 0.14 & 0.20 \\
\hline 2004 & 0.19 & 0.22 & 0.17 & 0.31 & 0.09 & 0.16 \\
\hline 2005 & 0.19 & 0.21 & 0.19 & 0.55 & 0.14 & 0.19 \\
\hline \multicolumn{7}{|l|}{ Cartel } \\
\hline 2003 & 0.52 & - & - & 0.44 & 0.31 & 0.31 \\
\hline 2004 & 0.50 & 0.56 & 0.48 & 0.39 & 0.22 & 0.23 \\
\hline 2005 & 0.48 & 0.68 & 0.39 & 0.72 & 0.31 & 0.22 \\
\hline \multicolumn{7}{|c|}{ Nested logit specification } \\
\hline \multicolumn{7}{|l|}{ Bertrand } \\
\hline 2003 & 0.52 & - & - & 0.15 & 0.07 & 0.22 \\
\hline 2004 & 0.47 & 0.49 & 0.39 & 0.13 & 0.04 & 0.16 \\
\hline 2005 & 0.58 & 0.45 & 0.42 & 0.17 & 0.06 & 0.22 \\
\hline \multicolumn{7}{|l|}{ Cartel } \\
\hline 2003 & 0.60 & - & - & 0.31 & 0.11 & 0.30 \\
\hline 2004 & 0.55 & 0.63 & 0.89 & 0.27 & 0.08 & 0.27 \\
\hline 2005 & 0.70 & 0.78 & 0.75 & 0.33 & 0.10 & 0.49 \\
\hline
\end{tabular}

This table reports the change of the average "observed" implied PCMs through time. The "observed" PCMs are calculated with the observed interest rates and estimated marginal cost. The implied PCMs calculated with the estimated demand elascticities. 


\section{Table 13}

Comparision of "observed" (accounting estimate of margins) and implied relative price-cost margins for each banks

\begin{tabular}{|c|c|c|c|c|c|c|}
\hline \multirow[b]{2}{*}{$\begin{array}{l}\text { In percentage of observations } \\
\text { Weighted by market shares }\end{array}$} & \multicolumn{3}{|c|}{ Consumer loans } & \multicolumn{3}{|c|}{ Household deposits } \\
\hline & Overdraft & $\begin{array}{c}\text { Higher } \\
\text { purchase loans }\end{array}$ & $\begin{array}{l}\text { Personal } \\
\text { loans }\end{array}$ & $\begin{array}{l}\text { Demand } \\
\text { deposits }\end{array}$ & $\begin{array}{l}\text { Short-term } \\
\text { deposits }\end{array}$ & $\begin{array}{l}\text { Long-term } \\
\text { deposits }\end{array}$ \\
\hline \multicolumn{7}{|c|}{ Logit specification } \\
\hline Observed margins lower than Bertrand & $\begin{array}{l}16.21 \\
9.43\end{array}$ & $\begin{array}{l}0 \\
0\end{array}$ & $\begin{array}{l}6.82 \\
3.05\end{array}$ & $\begin{array}{l}6.18 \\
2.72\end{array}$ & $\begin{array}{l}53.90 \\
54.36\end{array}$ & $\begin{array}{l}63.46 \\
57.38\end{array}$ \\
\hline $\begin{array}{l}\text { Observed margins between Bertrand } \\
\text { and cartel }\end{array}$ & $\begin{array}{l}42.43 \\
37.11\end{array}$ & $\begin{array}{l}12.82 \\
8.43\end{array}$ & $\begin{array}{l}37.84 \\
18.26\end{array}$ & $\begin{array}{l}32.63 \\
19.59\end{array}$ & $\begin{array}{l}18.98 \\
9.41\end{array}$ & $\begin{array}{l}26.70 \\
11.88\end{array}$ \\
\hline Observed margins higher than cartel & $\begin{array}{l}41.36 \\
53.46\end{array}$ & $\begin{array}{l}87.18 \\
91.57\end{array}$ & $\begin{array}{l}55.34 \\
78.69\end{array}$ & $\begin{array}{l}62.19 \\
77.69\end{array}$ & $\begin{array}{l}27.12 \\
36.23\end{array}$ & $\begin{array}{c}9.84 \\
30.74\end{array}$ \\
\hline \multicolumn{7}{|c|}{ Nested logit specification } \\
\hline Observed margins lower than Bertrand & $\begin{array}{l}45.65 \\
31.09\end{array}$ & $\begin{array}{l}23.07 \\
11.60\end{array}$ & $\begin{array}{l}21.01 \\
10.50\end{array}$ & $\begin{array}{l}3.09 \\
2.01\end{array}$ & $\begin{array}{l}25.94 \\
29.38\end{array}$ & $\begin{array}{l}54.38 \\
55.71\end{array}$ \\
\hline $\begin{array}{l}\text { Observed margins between Bertrand } \\
\text { and cartel }\end{array}$ & $\begin{array}{l}23.22 \\
41.18\end{array}$ & $\begin{array}{l}26.01 \\
31.71\end{array}$ & $\begin{array}{l}22.52 \\
63.01\end{array}$ & $\begin{array}{l}6.86 \\
5.35\end{array}$ & $\begin{array}{l}60.07 \\
11.66\end{array}$ & $\begin{array}{l}31.78 \\
38.91\end{array}$ \\
\hline Observed margins higher than cartel & $\begin{array}{l}31.13 \\
27.73\end{array}$ & $\begin{array}{l}50.92 \\
56.69\end{array}$ & $\begin{array}{l}56.47 \\
26.49\end{array}$ & $\begin{array}{l}90.05 \\
92.64\end{array}$ & $\begin{array}{l}13.96 \\
58.96\end{array}$ & $\begin{array}{c}13.84 \\
5.38\end{array}$ \\
\hline
\end{tabular}

This table reports the results of market power test. Banks are sorted in three intervals according to their "observed" PCMs: lower than the implied Bertrand value, between Bertrand and cartel value or above cartel value. We define the degree of competition low if the majority of observed values are higher than the implied values of Bertrand model. 


\section{Table 14}

Robustness test of nested logit specification using two nests

\begin{tabular}{|c|c|c|c|c|c|c|}
\hline & \multicolumn{3}{|c|}{ Consumer loans } & \multicolumn{3}{|c|}{ Household deposits } \\
\hline & Overdraft & $\begin{array}{c}\text { Higher } \\
\text { purchase loans }\end{array}$ & $\begin{array}{l}\text { Personal } \\
\text { loans }\end{array}$ & $\begin{array}{l}\text { Demand } \\
\text { deposits }\end{array}$ & $\begin{array}{l}\text { Short-term } \\
\text { deposits }\end{array}$ & $\begin{array}{c}\text { Long-term } \\
\text { deposits }\end{array}$ \\
\hline Interest rate & $\begin{array}{l}-0.14^{\star * *} \\
(-7.05) \\
\end{array}$ & $\begin{array}{l}-0.12^{* *} \\
(-2.16) \\
\end{array}$ & $\begin{array}{l}-0.08^{* * *} \\
(-4.90) \\
\end{array}$ & $\begin{array}{l}1.25^{\star \star \star} \\
(4.89) \\
\end{array}$ & $\begin{array}{l}2.25^{\star \star \star} \\
(7.84) \\
\end{array}$ & $\begin{array}{l}0.68^{\star * *} \\
(4.72) \\
\end{array}$ \\
\hline Service fee & - & - & - & $\begin{array}{l}-0.53^{\star \star *} \\
(-7.90)\end{array}$ & $\begin{array}{l}-0.35^{\star *} \\
(-2.45)\end{array}$ & $\begin{array}{l}-2.03^{\star * \star} \\
(-3.55)\end{array}$ \\
\hline Nest variable $(\overline{\mathrm{S}})$ & $\begin{array}{l}0.85^{\star \star \star} \\
(16.69)\end{array}$ & $\begin{array}{c}0.86^{\star \star \star} \\
(13.20)\end{array}$ & $\begin{array}{l}0.86^{\star \star \star} \\
(26.00)\end{array}$ & $\begin{array}{l}0.46^{\star *} \\
(2.11)\end{array}$ & $\begin{array}{l}0.39^{* *} \\
(1.92)\end{array}$ & $\begin{array}{l}0.46^{\star \star \star} \\
(7.45)\end{array}$ \\
\hline Number of branch & $\begin{array}{l}0.007^{\star * *} \\
(8.34)\end{array}$ & $\begin{array}{l}0.004^{\star * *} \\
(5.09)\end{array}$ & $\begin{array}{l}0.002^{\star * *} \\
(5.37)\end{array}$ & $\begin{array}{l}0.02^{\star \star \star} \\
(8.66)\end{array}$ & $\begin{array}{l}0.02^{* * *} \\
(7.93)\end{array}$ & $\begin{array}{l}0.02^{* \star \star} \\
(16.01)\end{array}$ \\
\hline Employees per branch & $\begin{array}{l}0.008^{\star \star \star} \\
(5.78)\end{array}$ & $\begin{array}{l}0.008^{\star * \star} \\
(5.39)\end{array}$ & $\begin{array}{l}0.002 \\
(1.08)\end{array}$ & $\begin{array}{l}0.002 \\
(4.38)\end{array}$ & $\begin{array}{l}0.06^{\star * \star} \\
(4.12)\end{array}$ & $\begin{array}{c}0.01 \\
(0.53)\end{array}$ \\
\hline Interest rate elasticity & -2.52 & -4.03 & -2.21 & 8.10 & 26.99 & 8.91 \\
\hline Service fee elasticity & - & - & - & -1.41 & -0.65 & -1.51 \\
\hline
\end{tabular}

\begin{tabular}{|c|c|c|c|c|c|c|}
\hline \multirow{2}{*}{$\begin{array}{l}\text { Nest } \\
\text { Instruments }\end{array}$} & \multicolumn{6}{|c|}{ Nest1: Universal banks; Nest2: Specialized banks } \\
\hline & \multicolumn{6}{|c|}{ Cost+BLP } \\
\hline First stage partial $R^{2}$ / interest rate & 0.31 & 0.66 & 0.39 & 0.29 & 0.26 & 0.28 \\
\hline First stage partial $R^{2}$ / service fee & - & - & - & 0.90 & 0.89 & 0.34 \\
\hline First stage partial $R^{2}$ / nest variable & 0.45 & 0.87 & 0.48 & 0.33 & 0.45 & 0.30 \\
\hline First stage $F$ test / interest rate & 26.66 & 14.98 & 14.66 & 20.76 & 11.67 & 9.37 \\
\hline First stage $F$ test / service fee & - & - & - & 513.79 & 519.48 & 13.77 \\
\hline First stage $\mathrm{F}$ test / nest variable & 51.66 & 73.06 & 21.96 & 15.78 & 49.81 & 18.42 \\
\hline Overidentification (P-value) & 0.12 & 0.47 & 0.10 & 0.13 & 0.24 & 0.10 \\
\hline
\end{tabular}

Means of relative PCMs

\begin{tabular}{l|l|l|l|l|l|ll}
\hline Observed PCM (with estimated c $\mathrm{j}_{\mathrm{j}}$ ) & 0.41 & 0.61 & 0.65 & 0.85 & 0.15 & 0.17 \\
\hline Bertrand PCM & 0.48 & 0.20 & 0.47 & 0.18 & 0.05 & 0.13 \\
\hline Cartel PCM & 0.57 & 0.48 & 0.74 & 0.47 & 0.28 & 0.25 \\
\hline
\end{tabular}

This table reports the 2SLS estimates of bank level loan and deposit services demand functions using nested logit specification and two nests. The dependent variables are the logarithms of market shares of each banks minus the outside good on different submarkets. The explanatory variables are the interests rates, service fee (on the consumer loan markets the annual charge (APRC) that includes all service fees), nest variables, bank characteristics (such as number of existing branches, employes per branches) and time dummies. $t$-statistics are reported in parenthesis. Above we report the computed average interest rate and service fee elasticities, PCMs and the characteristics of the estimations. 


\section{Table 15}

Robustness test of nested logit specification using real variables

\begin{tabular}{|c|c|c|c|c|c|c|}
\hline & \multicolumn{3}{|c|}{ Consumer loans } & \multicolumn{3}{|c|}{ Household deposits } \\
\hline & Overdraft & $\begin{array}{c}\text { Higher } \\
\text { purchase loans }\end{array}$ & $\begin{array}{l}\text { Personal } \\
\text { loans }\end{array}$ & $\begin{array}{l}\text { Demand } \\
\text { deposits }\end{array}$ & $\begin{array}{l}\text { Short-term } \\
\text { deposits }\end{array}$ & $\begin{array}{c}\text { Long-term } \\
\text { deposits }\end{array}$ \\
\hline Interest rate & $\begin{array}{l}-0.14^{\star \star *} \\
(-6.97) \\
\end{array}$ & $\begin{array}{l}-0.12^{\star \star \star} \\
(-3.28) \\
\end{array}$ & $\begin{array}{l}-0.09^{* \star *} \\
(-2.22) \\
\end{array}$ & $\begin{array}{c}0.20 \\
(1.38) \\
\end{array}$ & $\begin{array}{l}4.72^{\star \star \star} \\
(5.37) \\
\end{array}$ & $\begin{array}{l}0.71^{\star * *} \\
(5.78) \\
\end{array}$ \\
\hline Service fee & - & - & - & $\begin{array}{c}-0.31^{\star \star \star} \\
(-14.11)\end{array}$ & $\begin{array}{l}-0.30 \\
(-1.43)\end{array}$ & $\begin{array}{l}-0.16 \\
(-0.36)\end{array}$ \\
\hline Nest variable $(\overline{\mathrm{S}})$ & $\begin{array}{c}0.87^{\star \star \star} \\
(17.73)\end{array}$ & $\begin{array}{l}0.86^{\star \star \star} \\
(9.61)\end{array}$ & $\begin{array}{l}0.84^{\star \star \star} \\
(14.52)\end{array}$ & $\begin{array}{l}0.61^{\star \star *} \\
(8.80)\end{array}$ & $\begin{array}{l}0.38^{\star * \star} \\
(2.21)\end{array}$ & $\begin{array}{l}0.77^{\star \star \star} \\
(15.26)\end{array}$ \\
\hline Number of branch & $\begin{array}{l}0.006^{\star * *} \\
(6.77)\end{array}$ & $\begin{array}{l}0.005^{\star \star \star} \\
(4.09)\end{array}$ & $\begin{array}{l}0.003^{\star * *} \\
(5.31)\end{array}$ & $\begin{array}{l}0.01^{\star \star \star} \\
(3.46)\end{array}$ & $\begin{array}{l}0.03^{\star * *} \\
(6.89)\end{array}$ & $\begin{array}{l}0.01^{\star \star \star} \\
(11.37)\end{array}$ \\
\hline Employees per branch & $\begin{array}{l}0.007^{\star \star \star} \\
(5.67)\end{array}$ & $\begin{array}{l}0.001^{\star \star \star} \\
(5.19)\end{array}$ & $\begin{array}{l}0.01^{\star *} \\
(1.95)\end{array}$ & $\begin{array}{c}0.02 \\
(1.59)\end{array}$ & $\begin{array}{l}0.05^{\star \star \star} \\
(2.98)\end{array}$ & $\begin{array}{l}-0.005 \\
(-0.60)\end{array}$ \\
\hline Interest rate elasticity & -1.79 & -3.30 & -2.15 & 0.59 & 21.00 & 8.32 \\
\hline Service fee elasticity & - & - & - & -2.28 & -0.54 & -0.27 \\
\hline
\end{tabular}

\begin{tabular}{l|c|c|c|c|c|c}
\hline Nest & \multicolumn{7}{c}{ Nest1: OTP; Nest2: Universal banks; Nest3: Sp ecialized banks } \\
\hline Instruments & \multicolumn{7}{|c|}{ Cost+BLP } \\
\hline First stage partial R / interest rate & 0.39 & 0.57 & 0.46 & 0.37 & 0.27 & 0.22 \\
\hline First stage partial R / service fee & - & - & - & 0.68 & 0.20 & 0.27 \\
\hline First stage partial R / nest variable & 0.43 & 0.73 & 0.52 & 0.57 & 0.50 & 0.23 \\
\hline First stage F test / interest rate & 23.47 & 16.32 & 11.12 & 11.57 & 14.18 & 14.68 \\
\hline First stage F test / service fee & - & - & - & 15.50 & 14.14 & 16.74 \\
\hline First stage F test / nest variable & 41.73 & 33.81 & 32.87 & 43.47 & 57.01 & 9.59 \\
\hline Overidentification (P-value) & 0.78 & 0.46 & 0.11 & 0.19 & 0.99 & 0.10 \\
\hline
\end{tabular}

\begin{tabular}{l|l|l|l|l|l|l}
\hline Observed PCM (with estimated c $\mathrm{c}_{\mathrm{j}}$ ) & 0.32 & 0.56 & 0.71 & 0.72 & 0.12 & 0.17 \\
\hline Bertrand PCM & 0.61 & 0.32 & 0.41 & - & 0.06 & 0.16 \\
\hline Cartel PCM & 0.96 & 0.54 & 0.69 & - & 0.09 & 0.45 \\
\hline
\end{tabular}

This table reports the 2SLS estimates of bank level loan and deposit services demand functions using nested logit specification and real variables. Variables are deflated with consumer inlfation. The dependent variables are the logarithms of market shares of each banks minus the outside good on different submarkets. The explanatory variables are the interests rates, service fee (on the consumer loan markets the annual charge (APRC) that includes all service fees), nest variables, bank characteristics (such as number of existing branches, employes per branches) and time dummies. t-statistics are reported in parenthesis. 


\section{Table 16}

Robustness test of nested logit specification introducing credit risk and dealer cost

\begin{tabular}{|c|c|c|c|}
\hline \multirow[t]{2}{*}{ Means } & \multicolumn{3}{|c|}{ Consumer loans } \\
\hline & Overdraft & $\begin{array}{l}\text { Higher } \\
\text { purchase loans }\end{array}$ & $\begin{array}{l}\text { Personal } \\
\text { loans }\end{array}$ \\
\hline Risk premium (per cent) & 1.06 & 2.50 & 0.95 \\
\hline Dealer cost (per cent) & - & 3.00 & - \\
\hline $\begin{array}{r}\text { Observed absolute PCM (with estimated } \mathrm{c}_{\mathrm{jt}} \text { ) / corrected (per cent) with credit risk } \\
\text { with credit risk and dealer cost }\end{array}$ & $\begin{array}{l}7.04 \\
-\end{array}$ & $\begin{array}{l}17.78 \\
14.83\end{array}$ & $\begin{array}{l}18.92 \\
-\end{array}$ \\
\hline $\begin{array}{r}\text { Observed relative PCM (with estimated } \mathrm{c}_{\mathrm{jt}} \text { ) / corrected } \quad \text { with credit risk } \\
\text { with credit risk and dealer cost }\end{array}$ & $\begin{array}{l}0.31 \\
-\end{array}$ & $\begin{array}{l}0.54 \\
0.46\end{array}$ & $\begin{array}{l}0.59 \\
-\end{array}$ \\
\hline
\end{tabular}

Threshold value (per cent)

0.51

6.62

4.55

This table reports average of "observed" price-cost margins for consumer lending markets corrected with risk premium and dealer cost. Risk premium equals to non-performing loans/ total loans for households multiplied by interest rate using data of specialized banks. Average dealer cost is proxied by expenditures on fees and commissions to stock of higher purchase loans using data of specialized banks. The table also report threshold values. At the threshold values half of the observed margins is under, while the other half is above the implied Bertrand values. 


\section{Table 17}

Robustness test of nested logit specification using net deposit interest rate

\begin{tabular}{l|c|c|c}
\hline \multirow{2}{*}{} & \multicolumn{2}{|c}{ Household deposits } \\
\cline { 2 - 4 } & $\begin{array}{c}\text { Demand } \\
\text { deposits }\end{array}$ & $\begin{array}{c}\text { Short-term } \\
\text { deposits }\end{array}$ & $\begin{array}{c}\text { Long-term } \\
\text { deposits }\end{array}$ \\
\hline Net interest rate & $1.30^{* * *}$ & $1.28^{* * *}$ & $0.86^{* * *}$ \\
& $(6.43)$ & $(7.79)$ & $0.06)$ \\
\hline Nest variable $(\bar{S})$ & $0.41^{* * *}$ & $0.67^{* *}$ & $(9.38)$ \\
\hline Number of branch & $(1.17)$ & $(2.41)$ & $0.01^{* * *}$ \\
\hline Employees per branch & $0.02^{* * *}$ & $0.01^{* * *}$ & $(13.48)$ \\
& $(7.26)$ & $(5.42)$ & $-0.05^{* *}$ \\
\hline
\end{tabular}

\begin{tabular}{l|l|l|l|}
\hline Interest rate elasticity & 3.38 & 9.91 & 5.94 \\
\hline
\end{tabular}

\begin{tabular}{|c|c|c|c|}
\hline Nest & \multicolumn{3}{|c|}{ Nest1: OTP; Nest2: Universal banks; Nest3: Specialized banks } \\
\hline Instruments & \multicolumn{3}{|c|}{ Cost+BLP } \\
\hline First stage partial $R^{2} /$ net interest rate & 0.51 & 0.45 & 0.47 \\
\hline First stage partial $R^{2}$ / nest variable & 0.40 & 0.56 & 0.59 \\
\hline First stage $\mathrm{F}$ test / net interest rate & 16.69 & 16.12 & 15.69 \\
\hline First stage $\mathrm{F}$ test / interest rate & 15.78 & 19.97 & 20.45 \\
\hline Overidentification (P-value) & 0.12 & 0.13 & 0.12 \\
\hline \multicolumn{4}{|c|}{ Means of relative PCMs } \\
\hline Observed PCM (with estimated $\mathrm{c}_{\mathrm{jt}}$ ) & 0.98 & 0.19 & 0.26 \\
\hline Bertrand PCM & 0.41 & 0.08 & 0.16 \\
\hline Cartel PCM & 0.45 & 0.13 & 0.28 \\
\hline
\end{tabular}

This table reports the 2SLS estimates of bank level deposit services demand functions using nested logit specification and net deposit interest rates. Net interest rate denotes the difference of gross interest rate and service fee. The dependent variables are the logarithms of market shares of each banks minus outside good on different submarkets. The explanatory variables are the interests rates, nest variables, bank characteristics (such as number of existing branches, employes per branches) and time dummies. $t$-statistics are reported in parenthesis. See the text for description of variables and instrument sets. Above we report the computed average interest rate elasticities, PCMs and the characteristics of the estimations. 


\section{Table 18}

Results of nested logit specification for the household deposit market

\begin{tabular}{|c|c|c|}
\hline & \multicolumn{2}{|c|}{ Household deposit market } \\
\hline & Nominal variables & Real variables \\
\hline Interest rate & $\begin{array}{l}2.89^{\star \star \star} \\
(6.40)\end{array}$ & $\begin{array}{l}3.58^{\star \star \star} \\
(4.38)\end{array}$ \\
\hline Service fee & $\begin{array}{l}-0.54^{\star \star \star} \\
(6.94)\end{array}$ & $\begin{array}{l}-0.31^{\star \star \star} \\
(-6.66)\end{array}$ \\
\hline Nest variable $(\overline{\mathrm{S}})$ & $\begin{array}{c}0.40^{\star \star} \\
(1.97)\end{array}$ & $\begin{array}{l}0.31^{\star \star} \\
(1.99)\end{array}$ \\
\hline Number of branch & $\begin{array}{l}0.03^{\star \star \star} \\
(9.20)\end{array}$ & $\begin{array}{l}0.04^{\star \star \star} \\
(7.22)\end{array}$ \\
\hline Employees per branch & $\begin{array}{l}0.10^{\star \star \star} \\
(6.55)\end{array}$ & $\begin{array}{l}0.08^{\star * *} \\
(4.65)\end{array}$ \\
\hline Interest rate elasticity & 31.17 & 13.11 \\
\hline Service fee elasticity & -1.23 & -0.63 \\
\hline
\end{tabular}

\begin{tabular}{l|c|c}
\hline Nest & \multicolumn{2}{|c}{ Nest1: OTP; Nest2: Universal banks; Nest3: Specialized banks } \\
\hline Instruments & 0.22 & 0.25 \\
\hline First stage partial R / interest rate & 0.27 & 0.93 \\
\hline First stage partial R / service fee & 0.37 & 0.51 \\
\hline First stage partial R / nest variable & 15.24 & 676.75 \\
\hline First stage F test / interest rate & 20.16 & 53.91 \\
\hline First stage F test / service fees & 40.27 & 0.11 \\
\hline First stage F test / nest variable & 0.19 & 0.19 \\
\hline Overidentification (P-value) & Means of relative PCMs \\
\hline Observed PCM (with estimated c $\mathrm{j}$ ) & 0.16 & 0.09 \\
\hline Bertrand PCM & 0.04 & 0.16 \\
\hline Cartel PCM & 0.07 & \\
\hline
\end{tabular}

This table reports the 2SLS estimates of bank level deposit services demand functions using nested logit specification and nominal and real deposit interest rates. The dependent variables are the logarithms of market shares of each banks minus outside good on different submarkets. The explanatory variables are the interests rates, nest variables, bank characteristics (such as number of existing branches, employes per branches) and time dummies. $t$-statistics are reported in parenthesis. See the text for description of variables and instrument sets. Above we report the computed average interest rate elasticities, PCMs and the characteristics of the estimations. 


\section{Table 19}

Results of market power test for alternative specifications

\begin{tabular}{l|c|c|c|c|c|c}
\hline $\begin{array}{l}\text { Observed PCMs under the implied } \\
\text { Bertrand PCMs } \\
\text { In percentage of observations) }\end{array}$ & \multicolumn{3}{|c}{ Consumer loans } & \multicolumn{3}{c}{ Household deposits } \\
\hline & Overdraft & $\begin{array}{c}\text { Higher } \\
\text { purchase loans }\end{array}$ & $\begin{array}{c}\text { Personal } \\
\text { loans }\end{array}$ & $\begin{array}{c}\text { Demand } \\
\text { deposits }\end{array}$ & $\begin{array}{c}\text { Short-term } \\
\text { deposits }\end{array}$ & $\begin{array}{c}\text { Long-term } \\
\text { deposits }\end{array}$ \\
\hline Two nests & 39.85 & 8.97 & 23.66 & 0.88 & 28.78 \\
\hline Real variables & 64.05 & 15.49 & 13.15 & - & 27.92 & 54.00 \\
\hline Including credit risk and dealer cost & 75.69 & 41.03 & 31.57 & - & - \\
\hline Net deposit interest rate & - & - & - & 6.82 & 28.97 & 59.58 \\
\hline
\end{tabular}

This table reports the results of the market power test. Each cell contains the percentage of banks whose "observed" margins are lower than the implied Bertrand values in different robustness specifications. We define the degree of competition high if the majority of "observed" values are lower than the predicted values of Bertrand model. 
MNB Working Papers 2007/1

A Structural Empirical Analysis of Retail Banking Competition: the Case of Hungary

Print: D-Plus

H-1037 Budapest, Csillaghegyi út 19-21. 


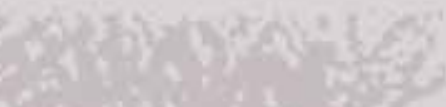

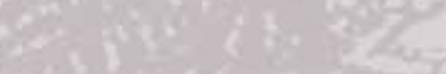

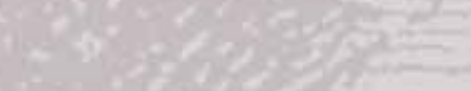

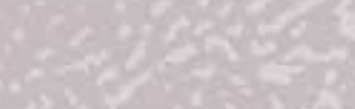

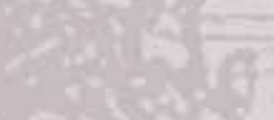

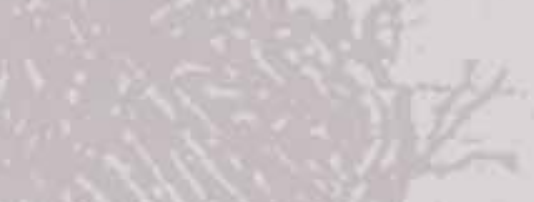

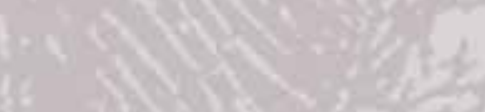

13.
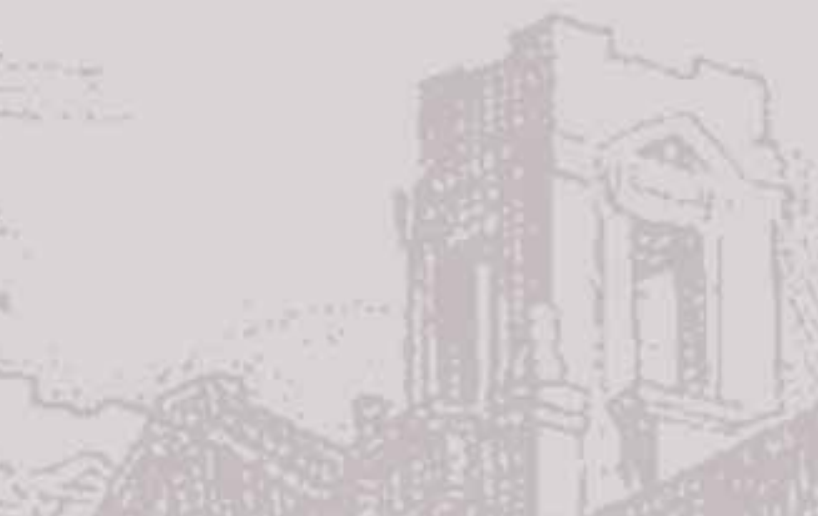
(7) 1 -g(t)

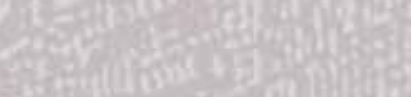

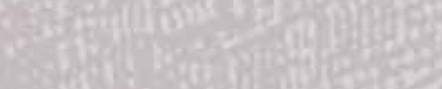

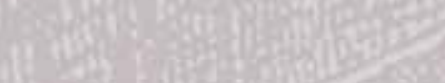

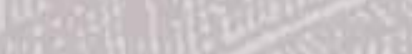

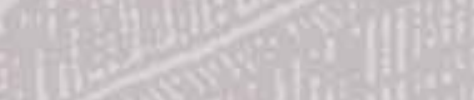

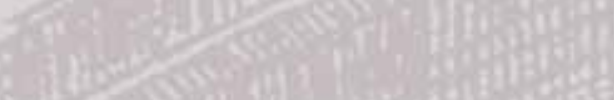

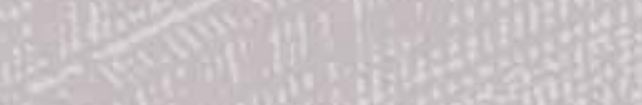

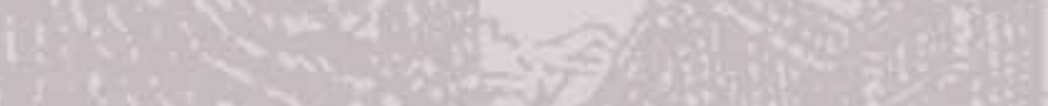

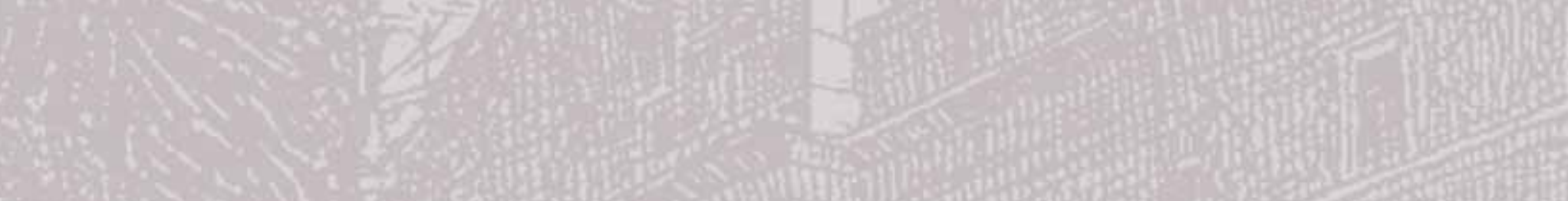

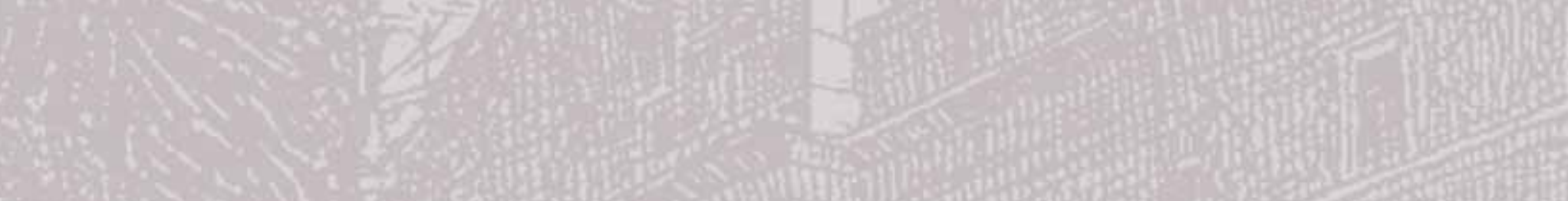

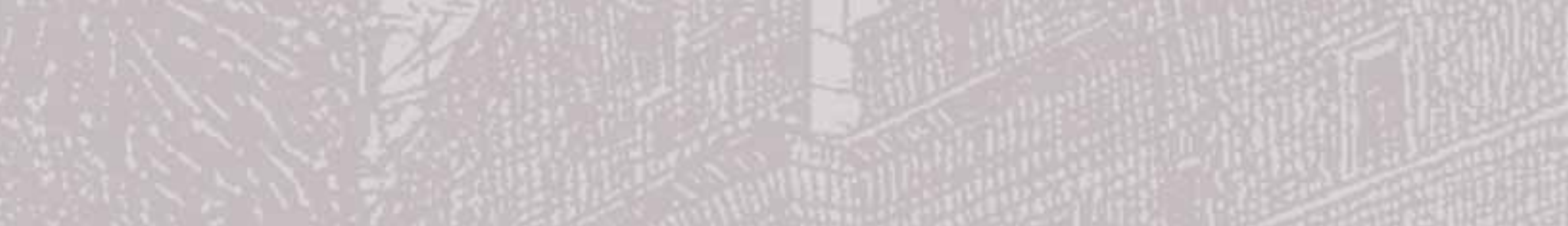

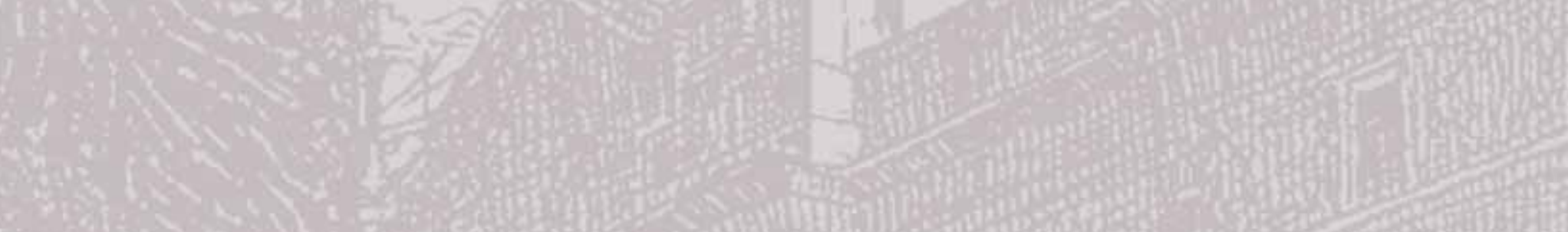
6.4.

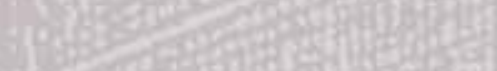

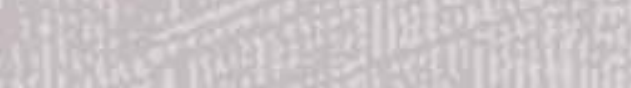
(ail 